
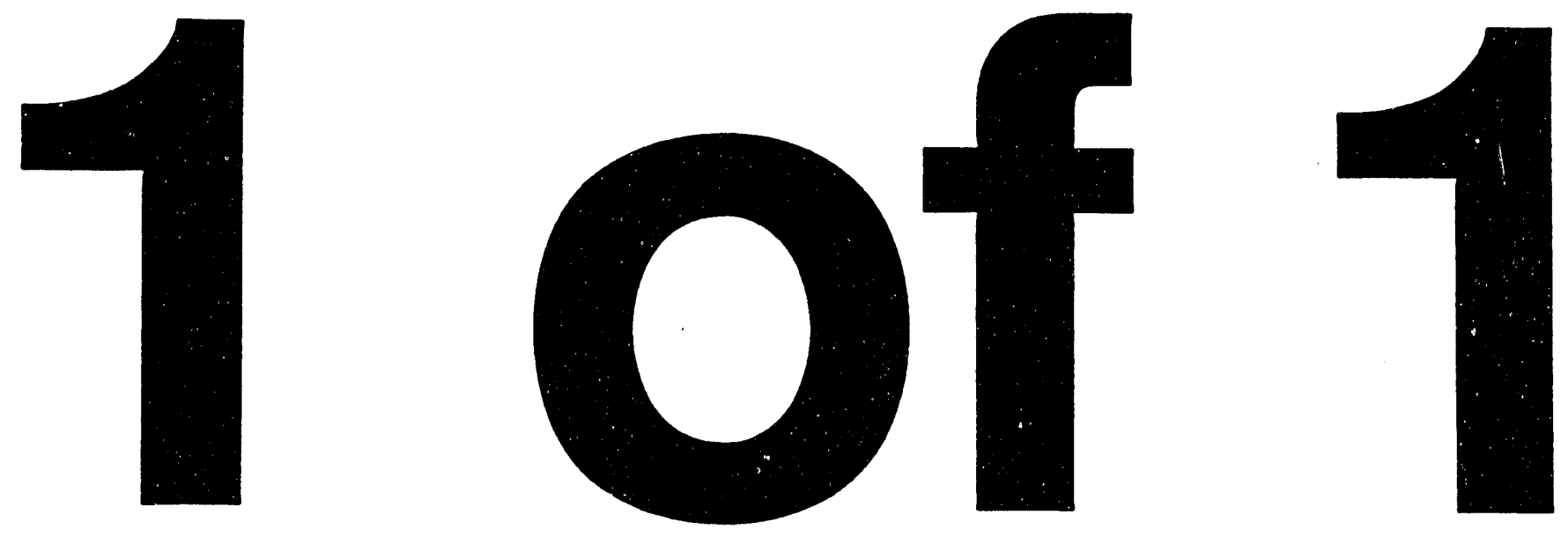


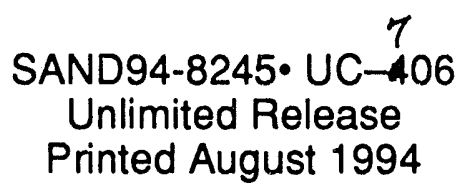

\title{
PIERCING TOOL TRANSPORTATION ACCIDENT RESISTANT CONTAINER (TARC)
}

\author{
Paul Lari \\ Stockpile Handling Equipment \\ Sandial National Laboratories / California
}

\begin{abstract}
Transportation Accident Resistant Containers (TARC)s are used for enhanced safety during movement of nuclear weapons. Its design features a tough stainless steel outer skin, redwood for impact mitigation and fire protection and a rugged aluminum inner container. Redwood absorts impact energy by crushing, similar to the way foam crushes in other containers. Red wood also functions to insulate the weapon from heat and fire. When a TARC is involved in a fire, the redwood will slowly burn forming a good insulating char. The redwood can continue to smolder once the fire is out. To ensure the smolder is extinguished, water can be directed into any accident caused hole in the skin. If no hole exists, it may be necessary to create one. This document discusses tool selection, testing, and a simple but effective method of creating an access hole in the outer skin large enough to apply fire fighting techniques.
\end{abstract}




\section{BACKGROUND}

Sandia National Laboratories began designing and testing accident resistant containers for nuclear weapons in the early 1970's. From that initial work has grown a family of Transportation Accident Resistant Containers (TARC) which include the H1501, H1501A, and H1501B containers. Appendix A, "Transportation Accident Resistant Containers", Robert Monson Sandia National Laboratories, Livermore, CA 94550, dtd 24 June 1992, provides a concise history of the development, design evolution, and capabilities of the TARC systems.

TARC's feature a tough stainless steel outer skin, redwood for impact mitigation and fire protection and a rugged aluminum inner container. Redwood absorbs impact energy by crushing, similar to the way foam crushes in other containers. Redwood also functions to insulate the weapon from heat and fire. In the event of a fire involving a TARC, the redwood starved for oxygen, burns slowly and forms a char that is a good insulator. After the flame is out, smolder of the redwood is likely. Detecting smolder by sensing heat and or puffs of smoke may be difficult. To ensure the smolder is out, water can be directed into any accident caused opening in the skin. The water will flood any smolder and eventually leak out the remaining $3 / 8$ inch vent holes. If only small holes or the vent holes exist, one of these holes can be used as a starting point for tools to create an opening large enough to flood the smolder with water.

Opening an access hole in the stainless steel skin can be difficult. Annealed 304 stainless steel is used because of its great ductility that allows the skin to stretci, bend, and buckle, but will not easily tear open. It provides a tough shell that holds the container together after impact. The H1501 and H1501A skin thickness are $1 / 8$ inch thick and the is H1501B is $3 / 16$ inch thick. Extinguishing the smolder would be one of the first actions taken by emergency crews arriving at the scene. One effective way of extinguishing the smolder is to introduce water beneath the stainless steel skin. In some situations it is necessary to create or enlarge an opening in the skin before water can be introduced. The skin's resistance to tearing require a proven access procedure and tools. The tools need to be portable, easy to use and do the job quickly. Energy powered tools are not recommended because they are not easily transported to an accident site and the possibility of spark induced fire or explosion. With these restrictions and requirements, only hand portable and operated tools were evaluated. 


\section{PIERCE TESTS}

Pierce tests were conducted to evaluate a selection of hand tool's capability to open a one inch access hole through the $1 / 8$ inch and $3 / 16$ inch thick stainless steel skins. All the tools had a chisel point, required a tool holder and needed to be hammered to cut the skins. Pierce Test- 1 , evaluated the Pyrolite Piercing Applicator's cutting performance on a $1 / 8$ inch stainless skin. Pierce Test-2, evaluated the Pyrolite Piercing Applicator and two out of three selected hand tools on $3 / 16$ inch stainless skin.

\section{TESTED TOOLS}

There is a wide range of cutting tools, wrecking bars and other assorted hand tools commercially available. Only a few of them were portable, easy to use and heavy duty enough to be considered capable of opening an access hole in the rugged outer skin of the TARC. The following were the tools selected for testing:

1. The Pyrolite Piercing Applicator, style 1088. This tool is a cutting tool and fire hose nozzle combined. It is $1^{1 / 2}$ inches in diameter and three feet long. It has a sharp hardened tool steel tip with water jet holes on one end that emit a dense fog pattern up to 95 Gallons Per Minute (GPM). The other end has a blunt driving button for hammering. Off to the side near the blunt end is a standard fire hose fitting. This tool is designed to penetrate mobile and concrete block homes and extinguish fire in walls and other difficult access areas. Figure 1, Item 1.

2. Concrete Gad or Bull Point, chisel. Its shaft is octagon shaped and has a taper square cutting tip and is approximately 12 inches long. This tool is normally used to break up concrete. Figure 1, Item 2.

3. Common Machinist Chisel, 1 inch wide flat blade by 12 inches long. Figure 1, Item 3.

4. Common Machinist Chisel, $3 / 4$ inch wide flat blade by 10 inches long. Figure 1, Item 4 .

5. Strap wrench (use with item 1.) Figure 1, Item 5.

6. Tool holder (use with items 2, 3, and 4) Figure 1, Item 6.

7. Sledgehammer, 15 pound (use with item 1,2 and 3) Figure 1, Item 7.

8. Hammer, 32 ounce (use with item 4) Figure 1, Item 8. 


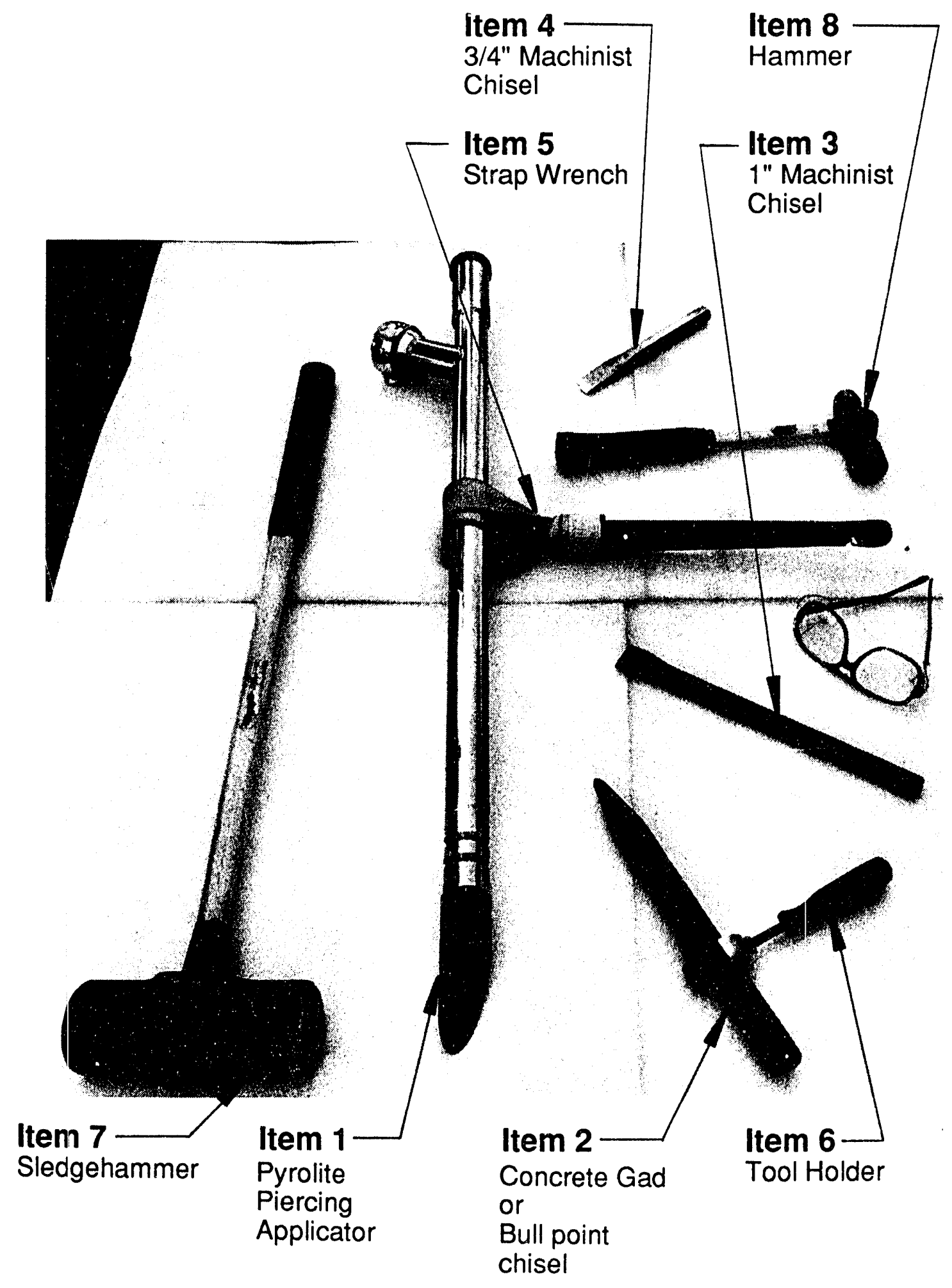

Figure 1 


\section{PIERCE TEST 1}

The objective of PIERCE TEST 1 was to evaluate the capability of a Pyrolite Piercing Applicator, style 1088 , to enlarge an existing a $3 / 8$ inch vent hole in the $1 / 8$ inch thick skin of an H1501 or H1501A TARC large enough to inject water.

An outer skin section of an H1501A from a previous drop and burn test was positioned horizontally on an asphalt surface. The Piercing applicator was positioned with the cutting tip placed in one of the holes near the container end (Figure 2). With one person placing the Piercing applicator cutting tip into a vent hole and steadying the tool with a Strap wrench, another person hammered the applicator drive button with a sledgehammer (Figure 3). After five blows of the sledgehammer, the piercing applicator began to cut into the skin (Figure 4). At this point the skin began to cut rapidly and at eleven blows, the tool shaft was through the skin creating a $11 / 2$ inch diameter hole (Figure 5 and 6). The piercing applicator was slightly bent and the cutting tip was dulled and deformed. The test was repeated on a similar vent hole using he same tool. After about ten blows of the sledgehammer, the piercing applicator began to cut the skin. At twenty blows, the applicator was through the skin. Figure 7 shows the deformation to the Pyrolite Piercing Applicator after successfully penetrating two vent holes in the skin.

\section{PIERCE TEST-1 RESULTS}

Even though the Pyrolite Piercing Applicator, style 1088 sustained some damage, it was successful in creating the desired access hole two times in the $1 / 8$ inch thick stainless steel skin and was in good enough shape to function as designed. 


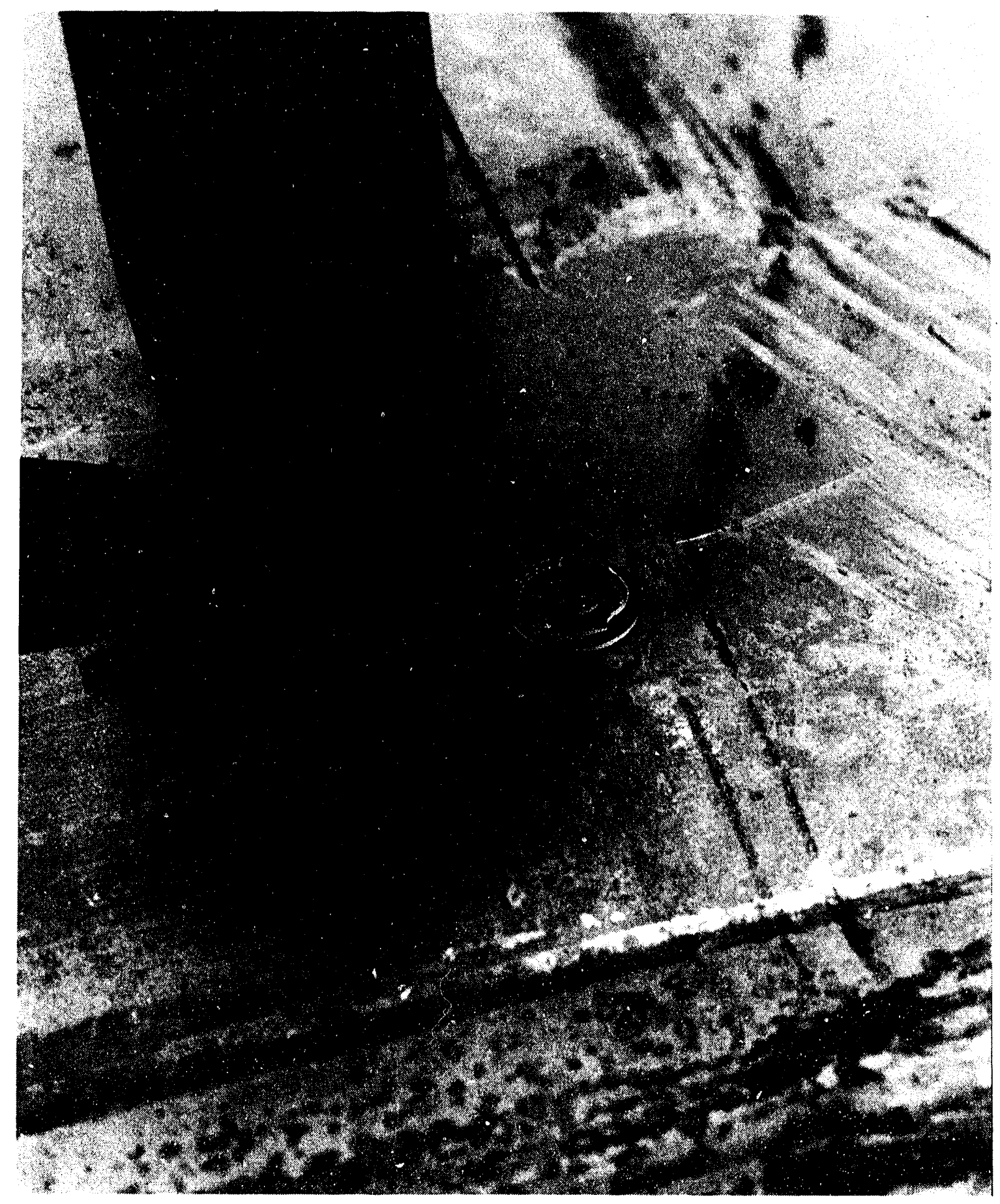

Figure 2 


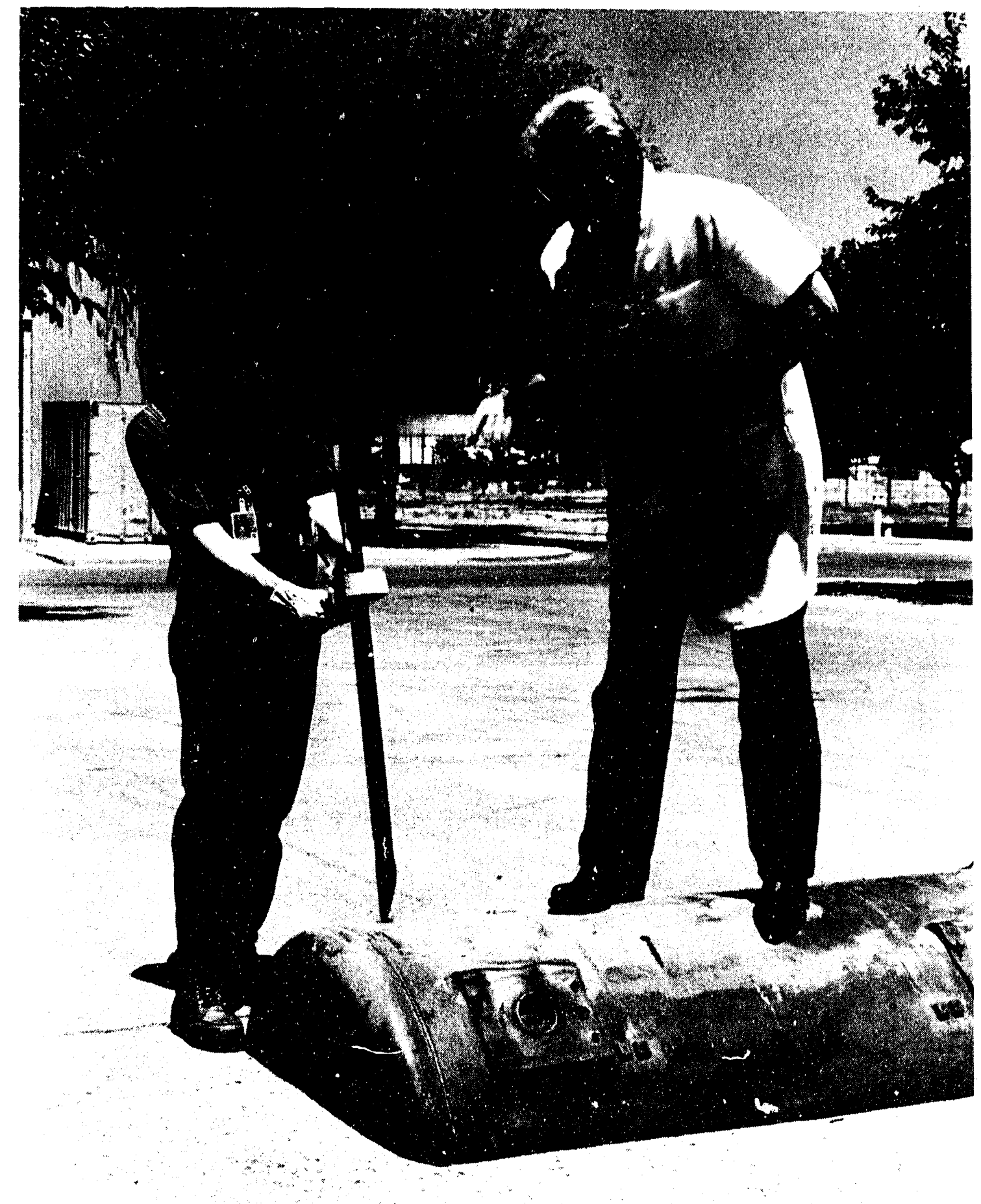

Figure 3 


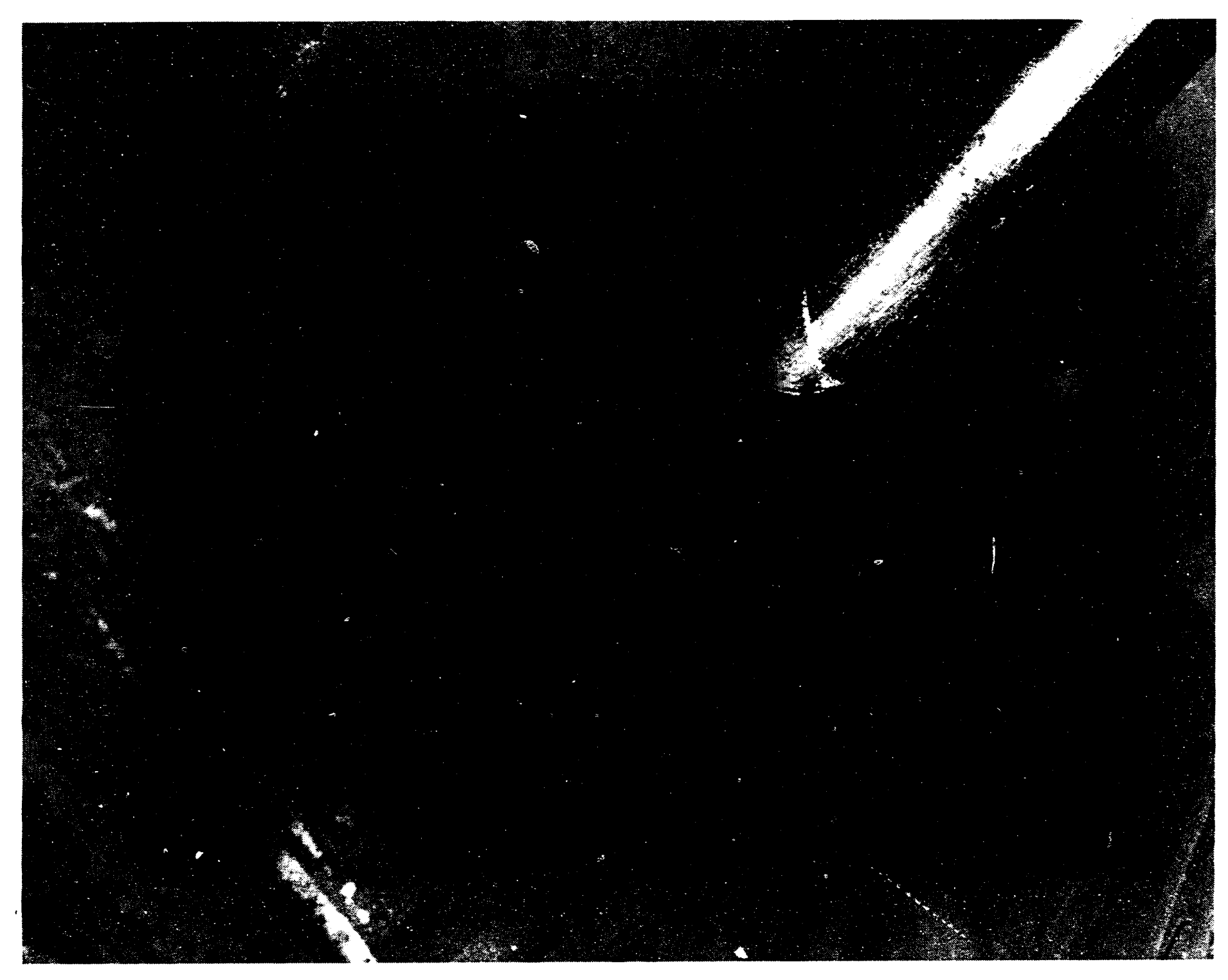

$\frac{+}{\frac{0}{3}}$ 


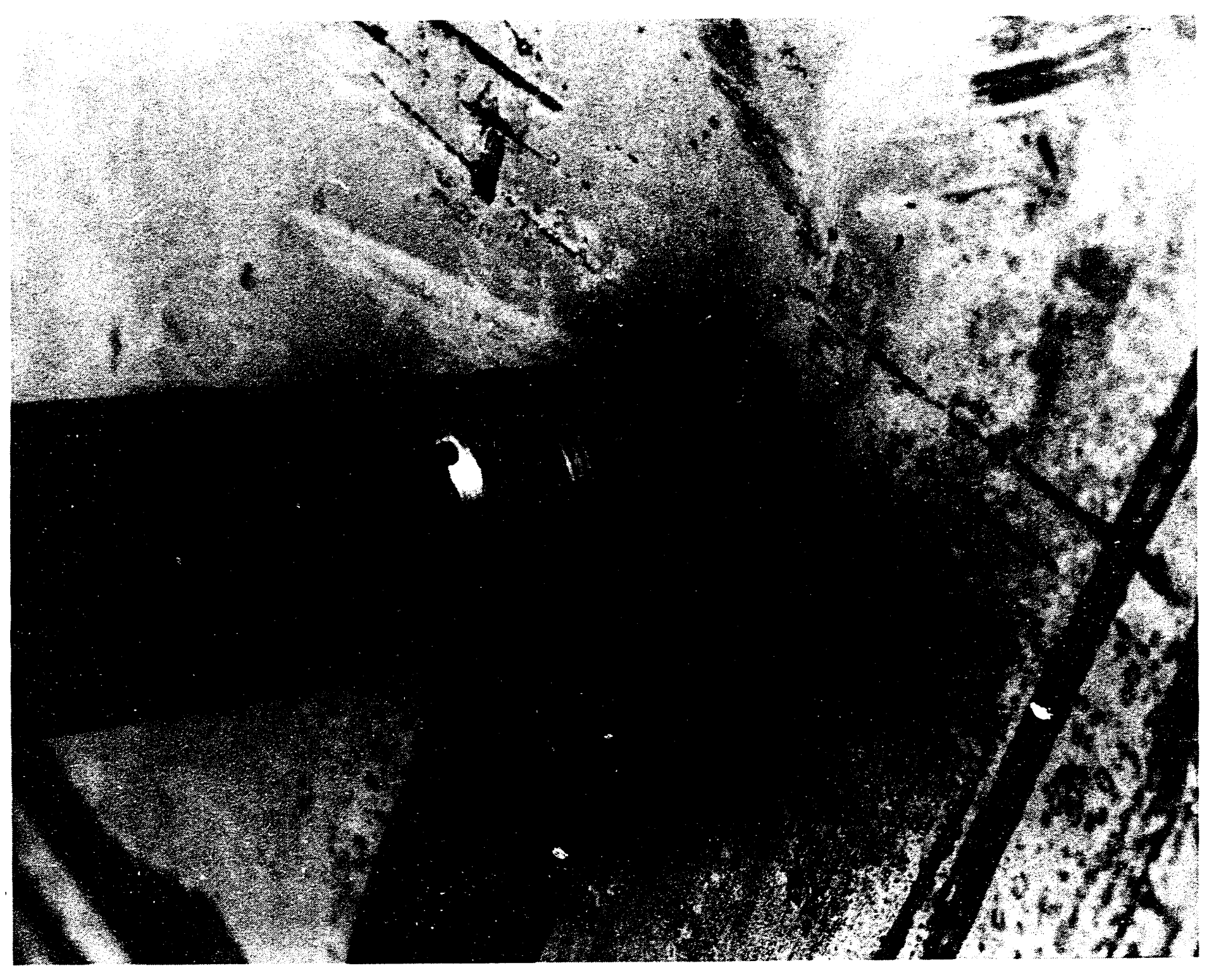

온 


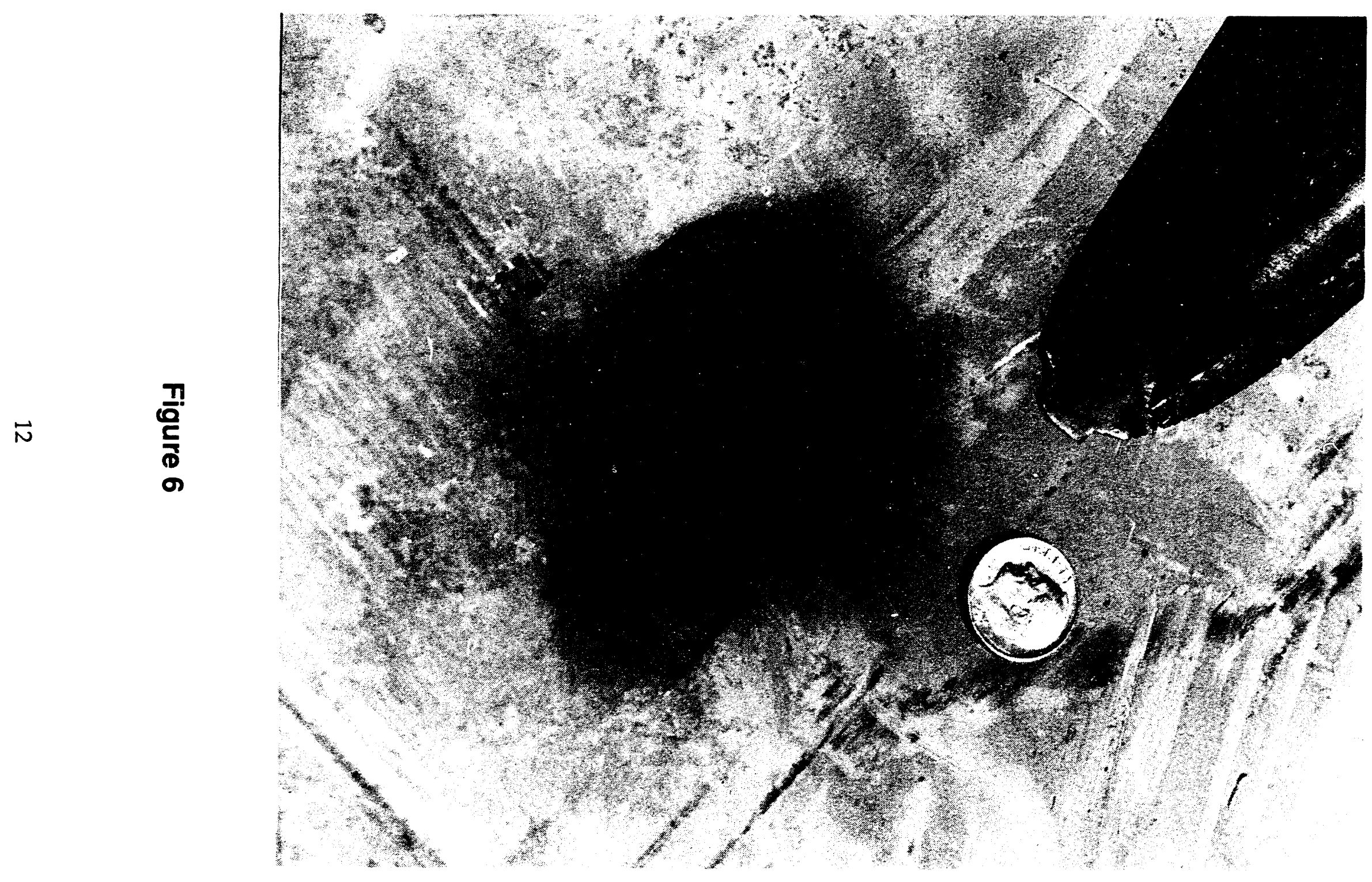




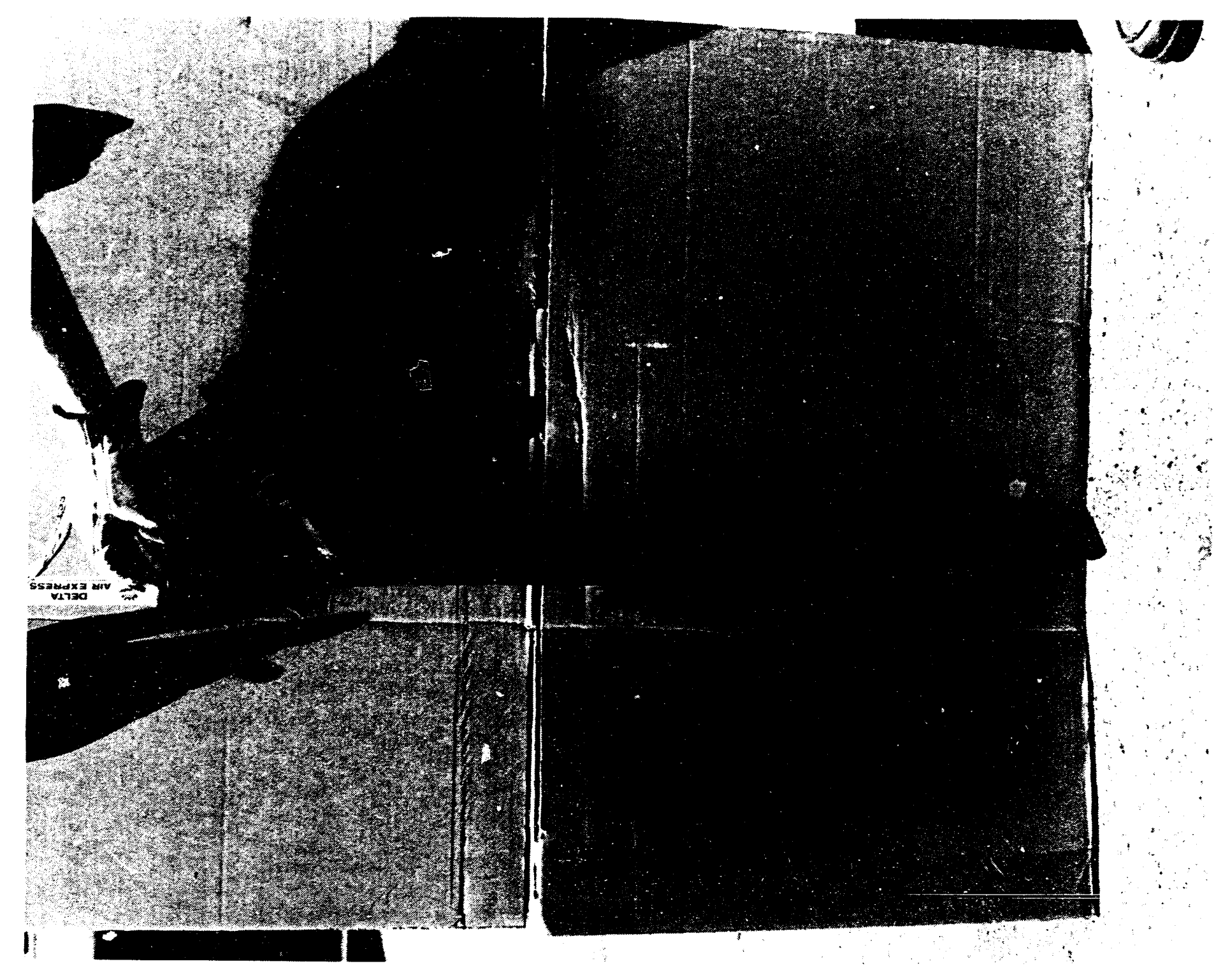

$\frac{1}{\frac{9}{5}}$ 


\section{PIERCE TEST 2}

The objective of PIERCE TEST 2 was to evaluate the capability of four different tools to open a $3 / 8$ inch vent hole in the $3 / 16$ inch thick skin of an H1501B TARC large enough to inject water. The tools tested were: a Pyrolite Piercing Applicator (Figure 1 Item 1), a bull point or gad chisel (Figure 1 Item 2) and a 1 inch wide blade chisel (Figure 1 Item 3 ). The a $3 / 4$ inch wide blade chisel (Figure 1 item 4 ) was not tested because It was determined at test time to be too small to cut the skin. All the tools were similar in use, requiring the use of two persons, a tool holder and a hammer. A mock-up skin section of a H1501B, part number A50288, was placed horizontally on an asphalt surface. Each tool was tested by positioning the cutting tip in one of the $3 / 8$ inch holes. With one person holding the tool with a tool holder, another person attempted to hammer the tool through the skin.

\section{TEST 2-1}

\section{CONCRETE GAD}

With one person positioning the cutting tip of the concrete gad (Figure 8 ) into the $3 / 8$ inch vent hole and firmly holding it with the chisel holder, another person hammered the cutting tool with a sledgehammer (Figure 9). At twenty blows with the sledgehammer, the gad produced a hole approximately $3 / 4$ inch by $3 / 4$ inch through the $3 / 16$ stainless steel skin (Figure 10). At thirty-six blows the gad cut through the skin enlarging the hole to about one inch by one inch square (Figure 11).

\section{TEST 2-2}

\section{PIERCING APPLICATOR}

With one person positioning the cutting tip into the $3 / 8$ inch vent hole and holding a new Piercing Applicator (Figure 1, Item 1) with the Strap wrench, another person hammered the cutting tool with a sledgehammer. At twenty blows with the sledgehammer, the test was halted due to the failure of the piercing applicator. The piercing applicators driving button cracked (Figure 12), the cutting point of the tool was blunted and chipped (Figure 13) and the body of the piercing applicator was bent and mushroomed at the joint where the hose connection was welded Figure 14). The tool was unable to cut the desired hole. It managed to dent and crease the area around the $3 / 8$ inch hole. 


$$
\text { I }
$$




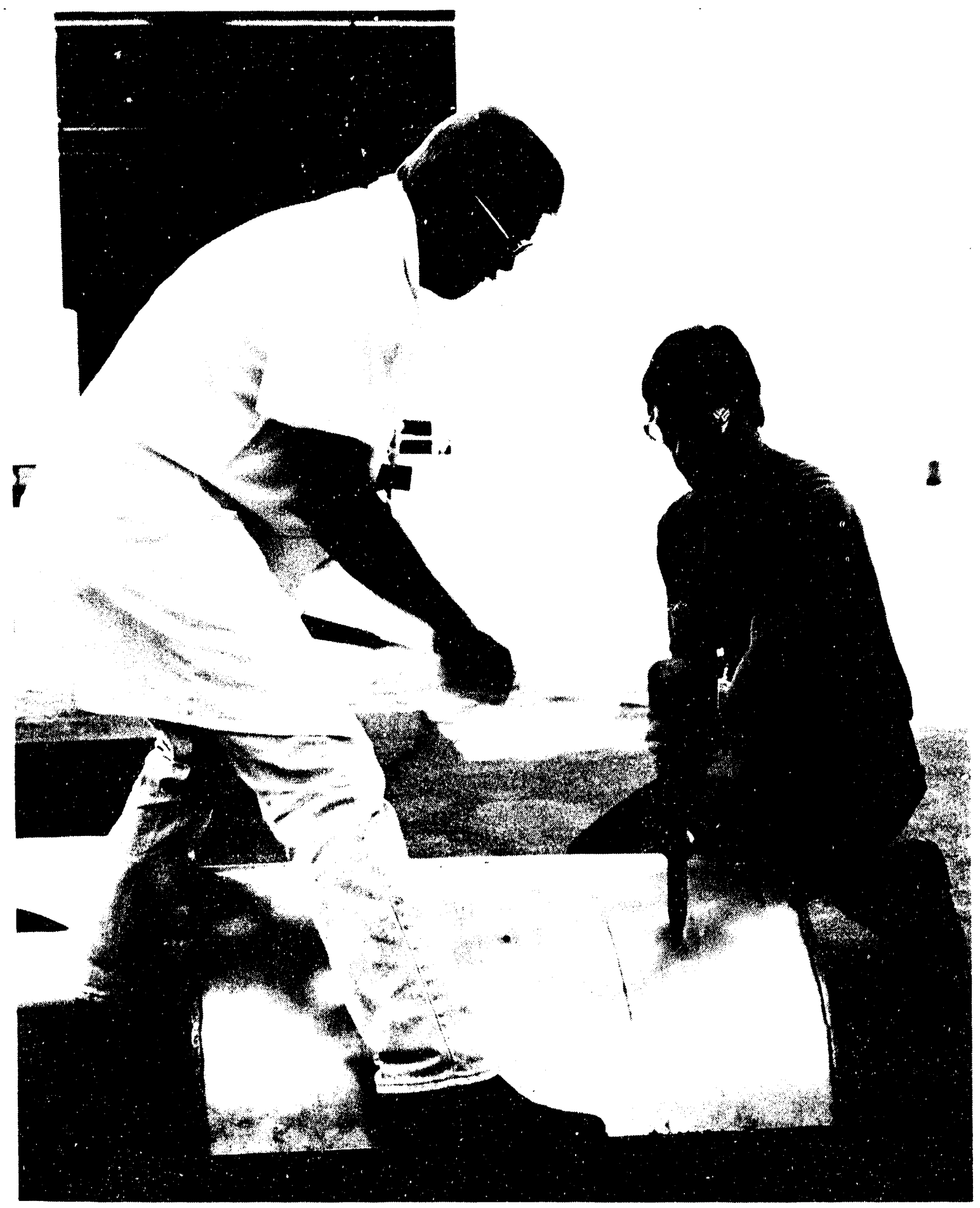

Figure 9 


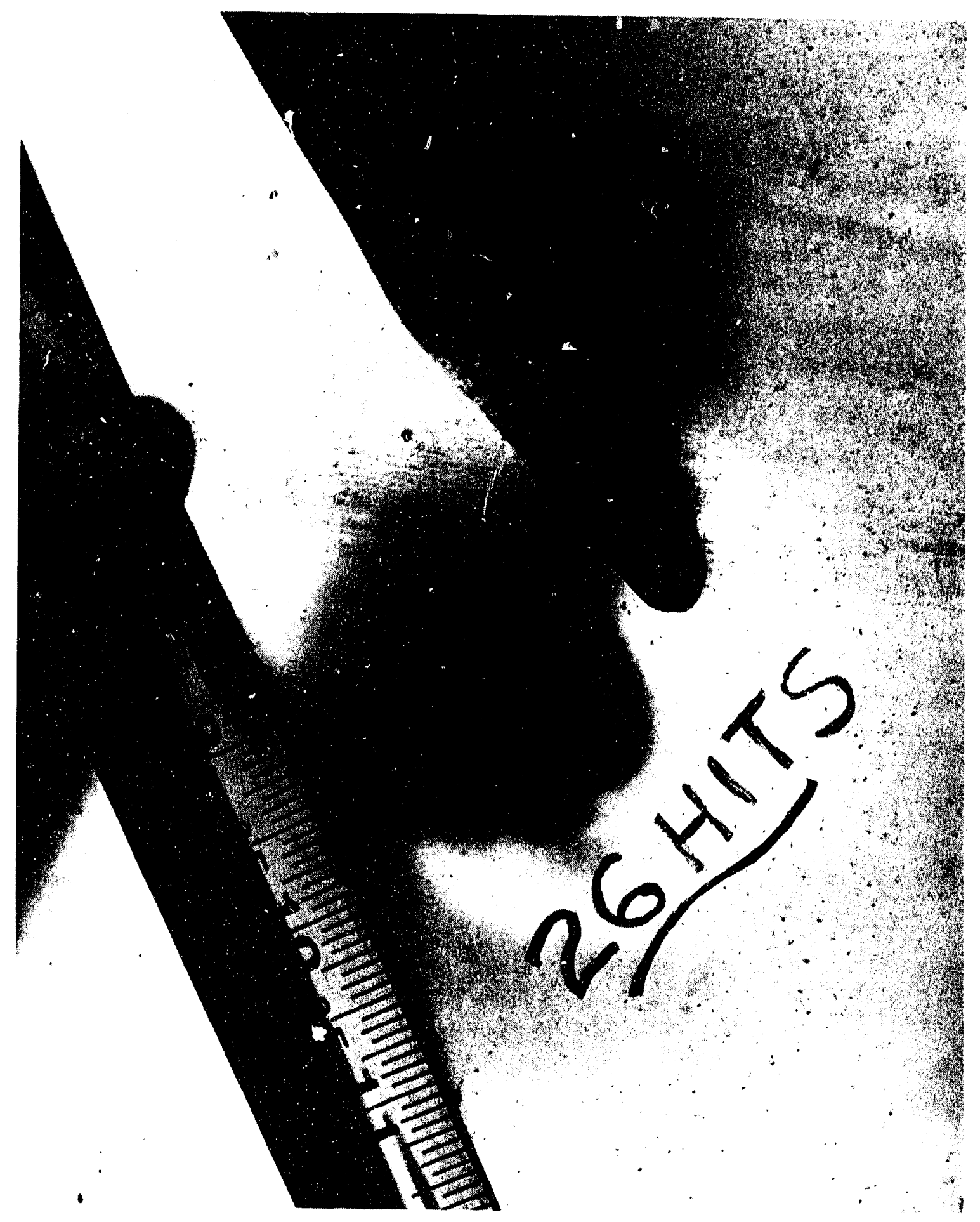

Figure 10 


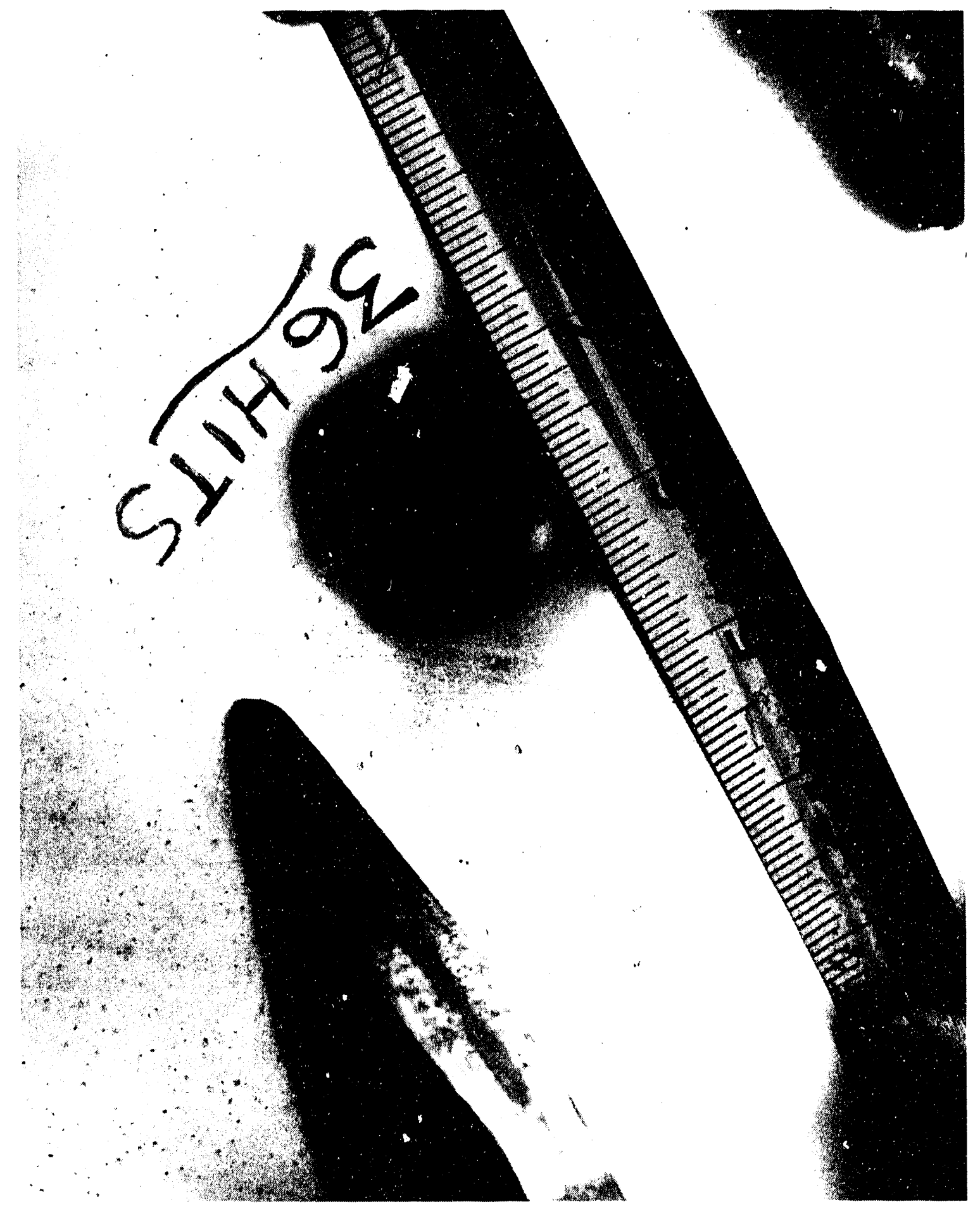

Figure 11 


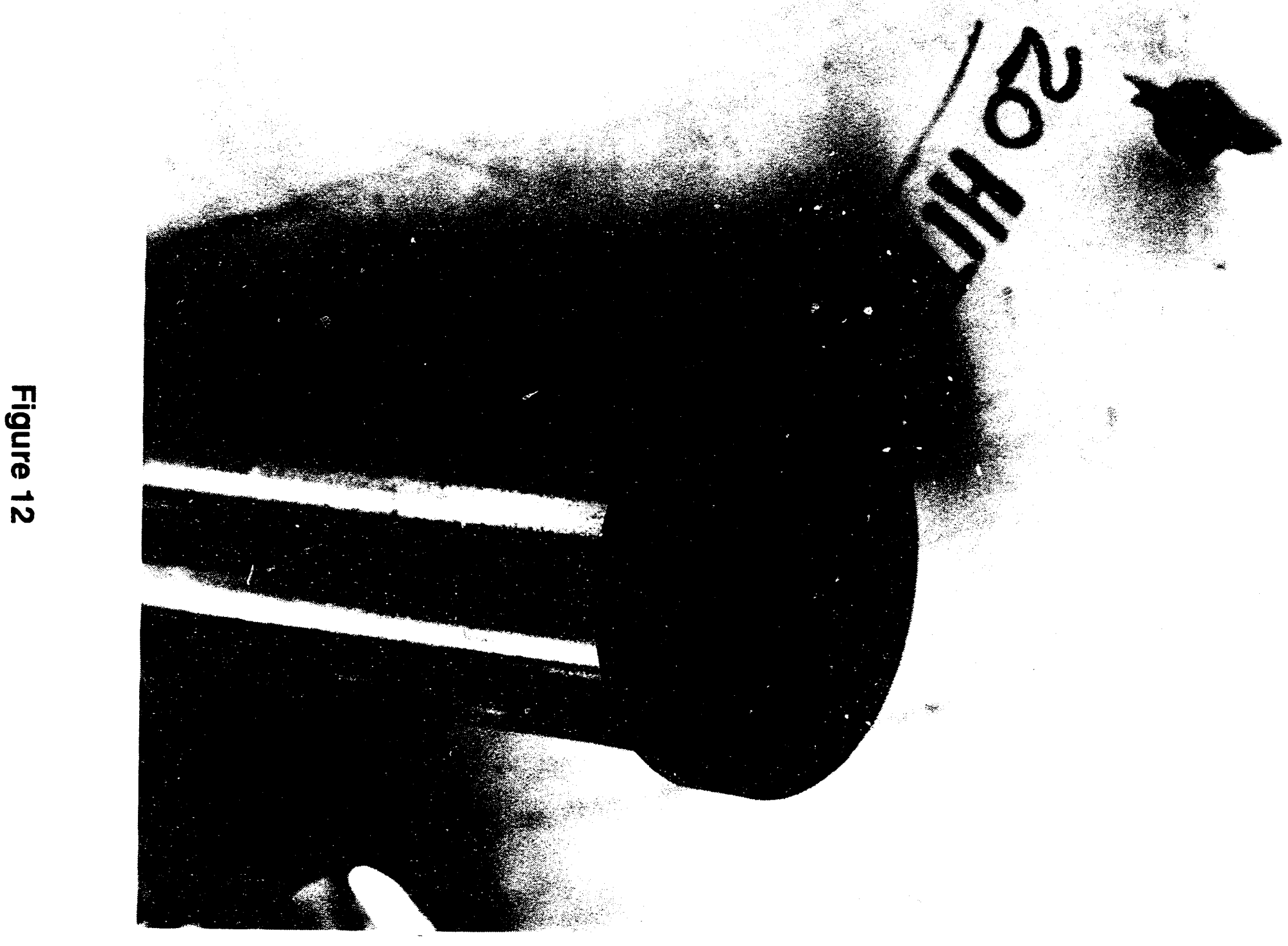




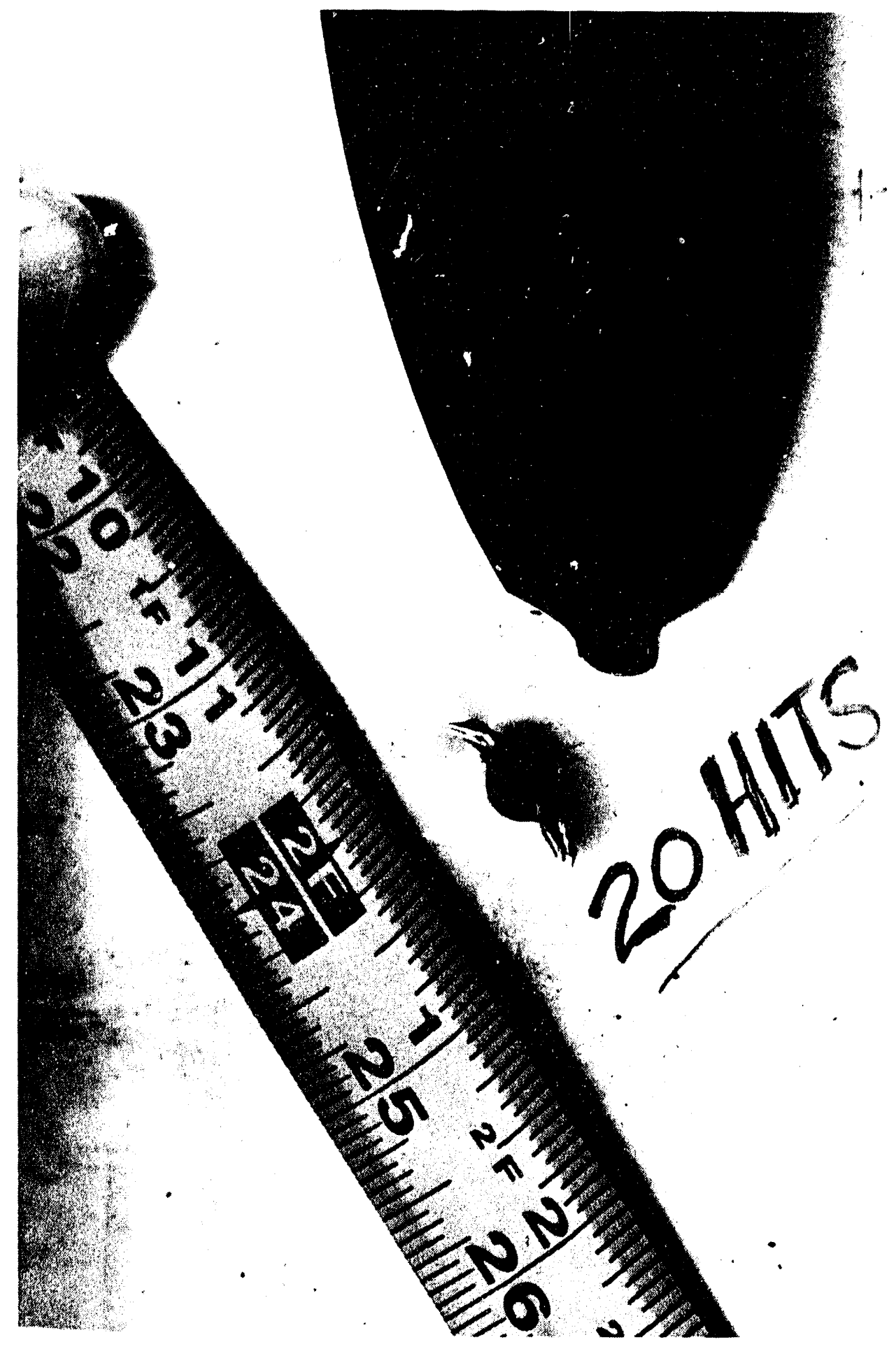

Figure 13 

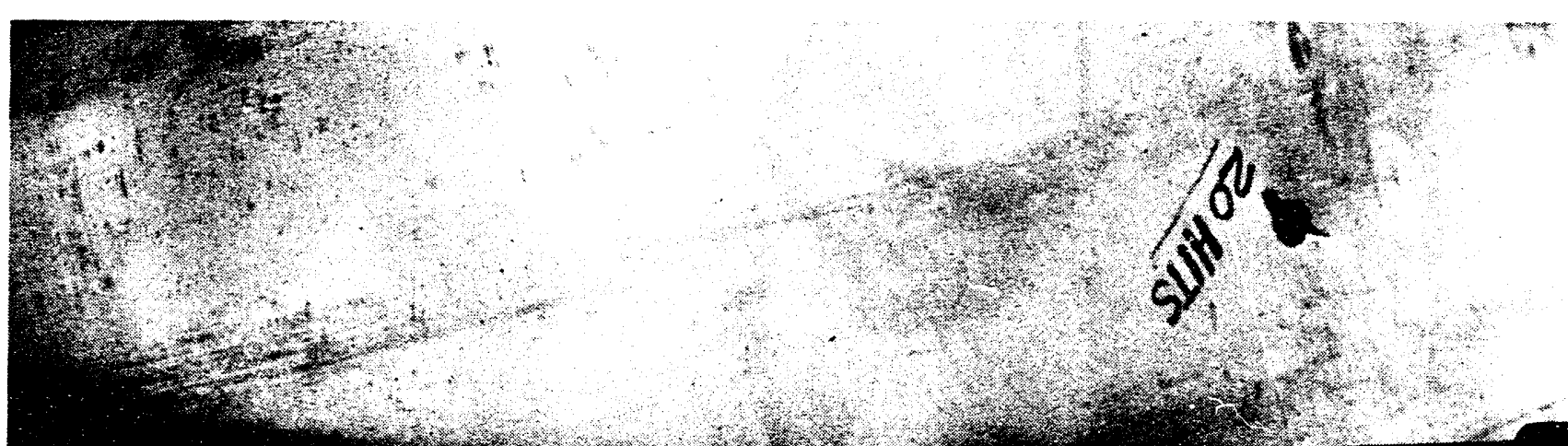

$\stackrel{\frac{7 n}{6}}{\frac{1}{D}}$

$\frac{\text { T! }}{\frac{1}{D}}$
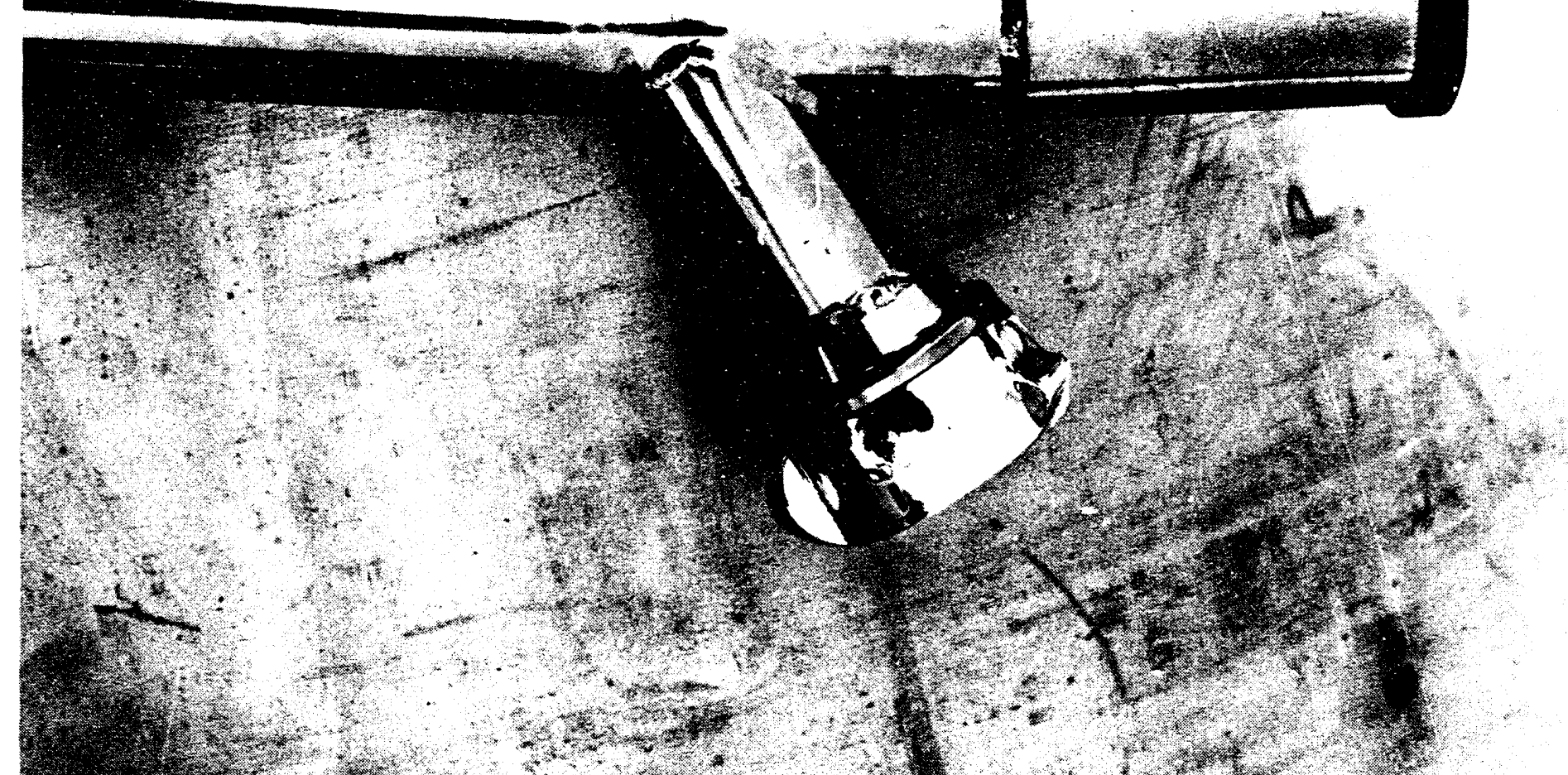


\section{TEST 2-3}

\section{CHISEL}

Position the mock-up section of a H1501B horizontally on an asphalt surface. Attempt to open one of the $3 / 8$ inch holes to at least a one inch hole using the chisel, chisel holder and ball peen hammer. Position the cutting tip of the chisel into a 3/8 inch hole near the test skin end. With one person holding the chisel with the chisel holder, another person hammers the cutting tool through the skin. Two cuts 90 degrees apart should be made. Bend a portion of the skin inwards with hammer and chisel or hammer alone. The end result should be at least a one inch by one inch hole.

After twenty blows with the ball peen hammer, it was apparent that the chisel was not going to cut the desired hole into the $3 / 16$ inch thick skin. The test was halted.

\section{PIERCE TEST 2 RESULTS}

The gad with its diamond tip cutting edge was the only' tool able to puncture the H1501B mock-up and create the desired access hole. The contriner skin was too stror.g for The piercing applicator or the chisel. The applicator was too weak to withstand the blows of the sledgehammer and became unusable before the desired hole was made. The one inch chisel and the 32 ounce hammer were too light weight to cut the $3 / 16$ skin.

\section{TOOL AND METHOD RECOMMENDATION}

An access hole in the TARC's $1 / 8$ to $3 / 16$ thick stainless steel skin can be created by a few simple easy to use hand tools. With two people using a concrete gad or bull point chisel, a tool holder and a 15 pound siedgehammer, a one inch access hole can be created. The method is simple, one person firmly positions the cutting tip of the gad into any $3 / 8$ inch vent hole located on the TA.RC, then the other person uses the sledgehammer to pound the gad into the vent hole. Once the gad expands the vent hole to a one inch hole, the tool is then removed. 


\section{APPENDIX A}

\section{TRANSPORTATION ACCIDENT RESISTANT CONTAINERS}




\title{
TRANSPORTATION ACCIDENT RESISTANT CONTAINERS
}

\author{
Robert Monson \\ Sandia National Laboratories \\ Livermore, CA 94550 \\ 24 June 1992
}

\section{History}

In the early 1970's SNL designed and built a container named ARC, short for Accident Resistant Container. Its design featured a stainless steel outer skin, redwood for impact mitigation and fire protection, and a thick aluminum inner container. The ARC was designed to prevent weapons from scattering plutonium in accidents as severe as an impact of 250 feet per second (FPS) followed by a 3 hour fuel fire. Extensive quarter- and full-scale testing demonstrated this capability. The ARC was a large container weighing 8000 pounds. Although it was compatible with $2 / 3$ of the 1975 stockpile, the DOE did not field it.

In the mid 1970's SNL designed and built a smaller container that could be carried on helicopters, the Helicopter Accident Resistant Container. The more modest design goals of the HARC were to prevent scattering plutonium in an impact of 100 FPS followed by a 90 minute fire. A series of 87 scale model tests helped engineers sort through several design variables. Full scale HARCs were built and ten successful tests verified the design goals. At the conclusion of the HARC program, surplus containers were put in storage. None were fielded.

\section{Design}

The redwood in accident resistant containers absorbs impact energy by crushing, similar to the way foam crushes in other containers. Unlike foam, its strength is strongly dependent on the direction it is crushed-parallel or perpendicular to the grain. The ratio of these strengths is roughly 9 , with the strongest direction parallel to the grain. In the ARC, the redwood was oriented to crush in the strong direction; for the HARC and the other containers discussed in this report, redwrood crushes in the weak direction. The orientation one chooses affects the $\mathrm{g}$ loads the weapon receives.

Redwood has another function and that is to insulate the weapon from heat in a fire. When starved for oxygen, it forms a char which also is a good insulator. The process of charring releases gasses that help to carry heat out of the container.

The stainless steel outer skin provides a tough shell that holds the container together after an impact and keeps air off the redwood in a fire. Stainless steel is used rather than other steels because of its great ductility. Stainless steel will stretch, bend, and buckle but it will not easily tear open. It normally has several small holes to let the gasses vent when the redwood chars. High strength tie down rings are mounted on the outer skin. 
The thick-walled inner container is relatively rigid compared to the outer skin and redwood. It supports the weapon and shields it from the large deformations experienced by the redwood and skin. The inner container has a stiff, bolted on door that usually is not sealed. An insert (or adapter) holds the weapon in the inner container. Although the insert may absorb some impact energy, its main function is to support the weapon in a predictable and beneficial way. It must be carefully designed to minimize damage to the weapon it holds in an accident.

The container is mounted on an aluminum base, or bolster, to make it easier to handle. The bolster has tie down rings and holes for forklift tines. Some have removable casters.

\section{H1501}

In $1987 \mathrm{SNL}$ responded to the Army's concern for safely moving W48 AFAPs on helicopters. The Army agreed to use accident resistant containers if they could be delivered in time. Sandia quickly converted the surplus HARCs into H1501s by adding paint, tie down rings, casters, W48 inserts, and auxiliary hardware. Twenty H1501 accident resistant containers were fielded. By 1991, four more newly built H1501s and 24 insert kits for holding W79 AFAPs inside the H1501 were fielded to support the Army's weapon movements. These containers were used on both helicopters and fixed-wing aircraft.

Sandia recognized that the capabilities of the H1501 were greater than the design goals of 100 FPS and 90 minutes. To better understand the limits of the container and the response of a W79 in it, Sandia and LLNL subjected two containers to impact and fire tests. Test Unit A impacted twice, first at 147 FPS oriented with the wheels down and then 105 FPS on the door end. A 2.5 hour long fuel fire test followed. Test Unit B impacted at 163 FPS and then was burned for 2 hours.

None of the impacts would have caused a real W79 to scatter plutonium. The temperature of both mock weapons was also well within the safe range during the burn and several days after as the redwood continued to smolder. In Test Unit A, the internal temperature was monitored for about 2 days as it smoldered and then data recording was terminated. This unit continued to smolder until it was dunked in water 9 days after the fire. This long duration smoldering was most likely caused by the many penetrations we made in the outer stainless steel skin to route instrumentation cables. These penetrations leaked air and sustained the smolder. Post-test examination of peak temperature indicators in Unit A showed that the mock weapon reached the marginal range sometime after the second day. Test Unit B, which was instrumented in a different way, also smoldered but it eventually went out on its own and the mock weapon remained acceptably cool.

\section{H1501A}

The W70 would not fit in an $\mathrm{H} 1501$ and the Army needed to move these weapons; therefore, in $1991 \mathrm{SNL}$ and the Army began a jointly funded program to develop a new container, the H1501A. Sandia agreed to cover the engineering 
costs while the Army paid for production. The H1501 A is similar to the H1501 except that the diameter of the payload cavity increased from 16 to 20 inches. Initially, the Army required $30 \mathrm{H} 1501 \mathrm{~A}$ containers with an equal number of inserts for the W48, W70, and W79. Auxiliary hardware kits were also needed. Later, the Army increased the quantity of W70 inserts and H1501A containers to 90 each. The Army also paid for the additional hardware needed to support testing and training. The Army's critical noeds for hardware have already been met and all hardware will be delivered by Inly 1992.

\section{H1501A Impact and Fire Testing}

Our testing philosophy is to test at or near what we understand to be the limits of the container-plus-weapon system. Sometime the weapon is the weak link in the system and other times it is the container. System capability is always sensitive to impact orientation.

So far, 5 H1501A containers have experienced impact tests. The first, Drop 1 , was intended to be a wheels up drop on a corner at 225 FPS. The container held a W48 structural mock. Unfortunately, a testing failure not related to the container resulted in an impact velocity of only 100 FPS. Although the container was only slightly damaged, the impact unexpectedly damaged the mock W48. This resulted in an immediate redesign of the insert which holds the W48 and a repeat test, Drop 1A, followed. Again, a testing failure ${ }^{1}$ resulted in only 100 rather than 225 FPS but with the new insert there was no warhead damage. The third attempt at this test, Drop $1 \mathrm{~B}$ resulted in an impact velocity of $185 \mathrm{FPS}^{2}$ with no warhead damage.

We used a new container and warhead for each of these three drops. Drop 3, discussed later, reused the container from Drop 1. The container from Drop $1 \mathrm{~A}$ is now a trainer.

After Drop 1B, the unit was burned for 2 hours over jet fuel. One of the goals of this test was to try out fire fighting techniques to extinguish smoldering redwood. This part of the test began 2 days after the burn. The most effective technique we found was to direct a jet of water into openings in the outer skineither impact-caused gashes or existing vent holes. During the burn and smolder, the temperature of the mock W48 stayed within the safe range. By the time we started fire fighting, the weapon had clearly established a cooling trend.

Drop 2 was our first test of a W70. It impacted at 232 FPS on its top side with the wheels pointed up. This is the orientation which causes the maximum $g$

\footnotetext{
${ }^{1}$ These impact tests are pull down rather than free fall tests. With the container suspended over the target, cables attached to a nearby rocket sled are rigged to the container. The rockets pull the container down with enough force to give it an acceleration of several g's. In both test failures, the pull down cables broke. This precipitated a detailed analysis to understand the dynamic forces in the cables and the effects of delay time between ignition of each rocket on the sled. A group of peers reviewed and accepted the analysis as accurate. The new policy of the test facility is to analyze in detail each significantly new configuration before testing.

${ }^{2}$ An electrical failure caused cable cutters to fire before the container had reached 225 FPS. This was most likely caused by debris kicked up by the rockets and is unrelated to the broken cables on drops 1 and $1 \mathrm{~A}$.
} 
loading to the container and its contents. The outer skin and door deformed as expected but did not tear and no bolts broke. The 4 caster assemblies broke free and gashed the outer skin in three places. Some of the inner door bolts sheared when the inner container ovaled but the inner door remained attached. The mock W70 sustained damage as expected, including cracks in the mock high explosive (HE). After the burn test, which is described next, and disassembly, LLNL determined that the impact would not have caused an explosion had the $\mathrm{HE}$ been real.

The container from Drop 2 was used in Burn 2, a 2 hour jet fuel fire test. The redwood inside the container continued to smolder until it was extinguished after nine hours. This action prevented the warhead temperature from possibly reaching a point where the mock HE would be damaged, complicating post-test analysis. Whether or not the warhead would have reached a temperature high enough to cause concern with real $\mathrm{HE}$ is unknown. Certainly the caster-caused gashes and a brisk wind contributed to the smoldering. However, during the nine hours the temperature remained in the safe range.

Drop 3 also included a mock W70 warhead. In this test, the H1501A impacted at 227 FPS on the door end. This orientation was picked primarily to investigate the weapon's response to an end drop. The H1501A performed well with no openings or gashes in the outer stainless steel skin. Most of the crush and deformation occurred on the impact end as the container shortened by about 4 inches. Radiographs show damage to the mock W70 as expected, but its significance has yet to be determined. Because of the good condition of the container and the likelihood of an unremarkable test, this unit was not burned.

\section{Vibration Testing}

Each weapon/container combination has been or will be vibration tested. The vibration test levels include the conditions that a weapon could see during normal transfortation and handling while inside an accident resistant container. We want to ensure that the weapon safety or reliability is not degraded.

\section{H1501B and Inserts for Bombs}

A new container, the H1501B, has been designed and is now in production. Essentially a longer version of the H1501A, this container can accommodate the center section of a B61. Other design changes include a $50 \%$ thicker stainless steel skin, more tie down lugs, white paint, and stronger doors. The first of an eventual 50 of these containers will be available in mid July. Test and training assets will also be built.

In production too, are three insert kits for bombs. One will hold the $\mathrm{B} 61 \mathrm{in}$ the H1501B. The other two are for B57s in the H1501 and H1501A containers. The first of the B57 inserts have already been fabricated along with equipment for loading and unloading bombs.

With this new container we have also adopted a new name. Each container in the H1501 family is now referred to as a Transportation Accident Resistant Container (TARC). This is more appropriate than HARC, which incorrectly implies that they are only for helicopter use. 


\section{Analytical Capability}

Our analytical capability is an important tool we use to understand the limits of these containers with their weapons, treated as a system. Analysis and testing reinforce each other. We use analysis to help refine the design and determine test conditions. Testing validates the design and analytical model. In general, Sandia's model focuses on the performance the container and weapon insert. LLNL's (and eventually, LANL's) models of the weapons indicate how the weapons will respond to the impact environment inside the container.

Sandia's 3-D model uses state-of-the-art failure models and data from extensive foam and redwood testing. It incorporates directional redwood properties. The concrete target is also included in the model since it absorbs kinetic energy at higher velocities. The model can now accurately predict impact g loads and container deformations, usually to within $10 \%$.

An interesting result is that the container's response is nearly independent of payload. Therefore, we believe that the calculations of the H1501 \& H1501A with a B57 are accurate even though there has not yet been a test. Also, since the main difference between an H1501A and an H1501B is in length, current results are applicable to H1501B.

\section{Manuals}

Fielding containers obligates us to write new manuals and revise others. For the Army's use of the H1501 and H1501A containers, we wrote Operation and Maintence manuals using the normal LTG/JTG (Laboratory/Joint Task Group) process. Manuals are now being written to support the Navy's and Air Force's use of the H1501, H1501A, and H1501B.

The Explosive Ordnance Disposal manuals, TP 60-1, and the -6 manual for each weapon was revised to reflect the new containers which could be involved in an accident. New techniques for gaining access to weapons were also needed since accident resistant containers are quite robust. Typically, shipping and handling containers for weapons are thin-skinned and made of aluminum. Normal EOD hand tools which cut (assuming cutting is necessary) aluminum are impractical or useless on stainless steel. To remedy this, the Army purchased two sets of hydraulically powered tools to aid in gaining access to weapons after an accident.

The Fire Fighting manual, TP 20-11, was also revised to show the characteristics of these TARCs. We have incorporated techniques learned in Burn 1B into this manual.

\section{Aircraft Compatibility}

Tie down procedures have been developed for the H1501 and H1501A containers, both with and without pallets in several aircraft. Procedures for the $\mathrm{C} 130$ and $\mathrm{C} 141 \mathrm{~B}$ fixed wing and $\mathrm{CH} 46, \mathrm{CH} 47$, and $\mathrm{CH} 53$ rotary wing aircraft exist in DOE and DoD documents. Tie down procedures for the H1501B have not yet been developed however, it should be straightforward. We have 
consulted with Air Force and Navy representatives and implemented their recommendation of adding 4 additional tie down lugs to the H1501B.

\section{Benefits}

The weapons which are most sensitive to scattering plutonium are those that do not have insensitive high explosives. Both impact and fire can cause a high-order reaction in the $\mathrm{HE}$, resulting in scattered plutonium .

In 1989 the Nuclear Weapons Council formed the Transportation Study Steering Group (TSSG). The charter of the TSSG was to asses the relative safety and security risks of peacetime logistical transportation of nuclear weapons.

Probabilistic risk assessment was one of the tools they used in their study. The TSSG concluded that accident resistant containers can reduce the chances of plutonium dispersal by an order of magnitude for certain weapons.

A different study by Sandia looked at the severity and frequency of aircraft accidents. The results here indicate that TARCs can prevent plutonium dispersal in about $95 \%$ of all aircraft accidents.

\section{Closing}

This narrative gave a brief overview of some of the important features of the Transportation Accident Resistant Container program at Sandia National Laboratories. These containers are effective at reducing the chance of plutonium dispersal in transportation accidents.

The technology used in these containers has been extensively tested and analyzed. A significant effort has been devoted to preparing manuals, without which the containers can not be used.

The program continues. By summer's end, we will be able to field all the hardware and manuals necessary to transport B57's and B61's in accident resistant containers. By then the TARC family will include 3 containers (H1501, H1501A, H1501B) and inserts for 5 weapons (W48, B57, B61, W70, W79).

Several illustrations follow this text. They show the H1501, H1501A, H1501B, a comparison of containers, and a summary of testing. 


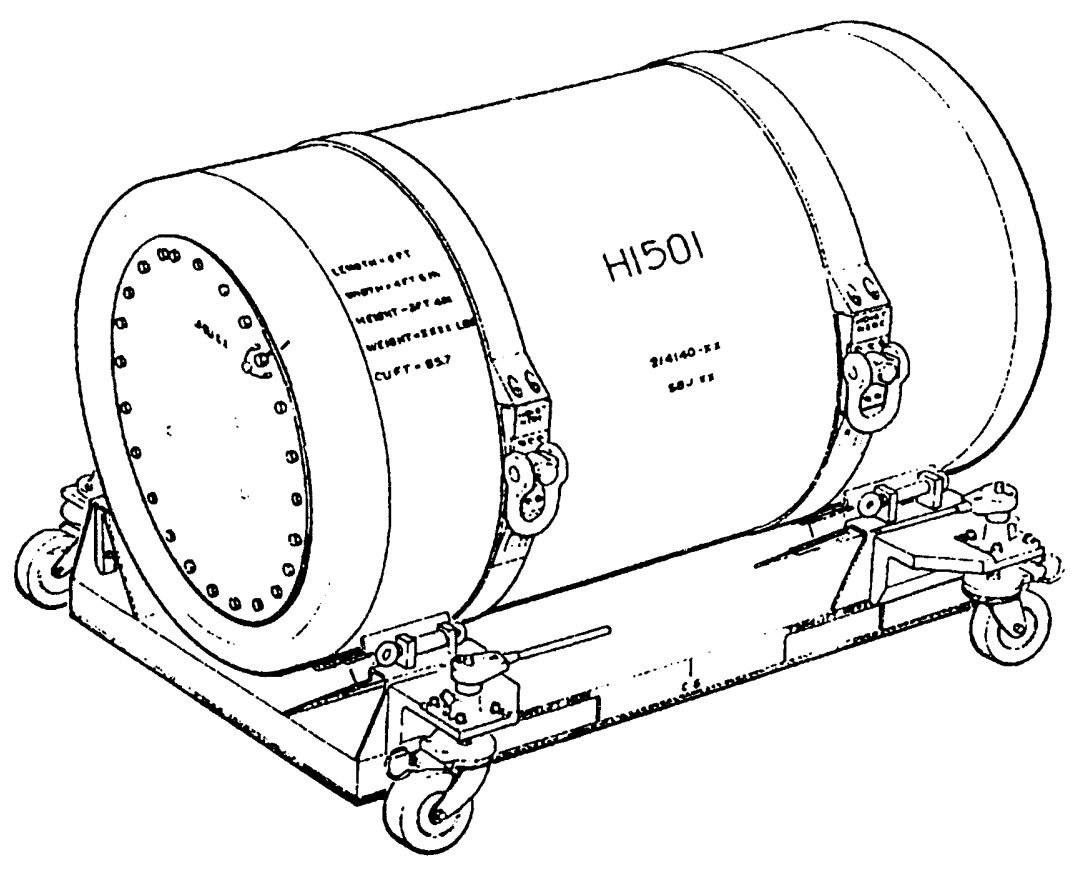

H1501 Transportation Accident Resistant Container

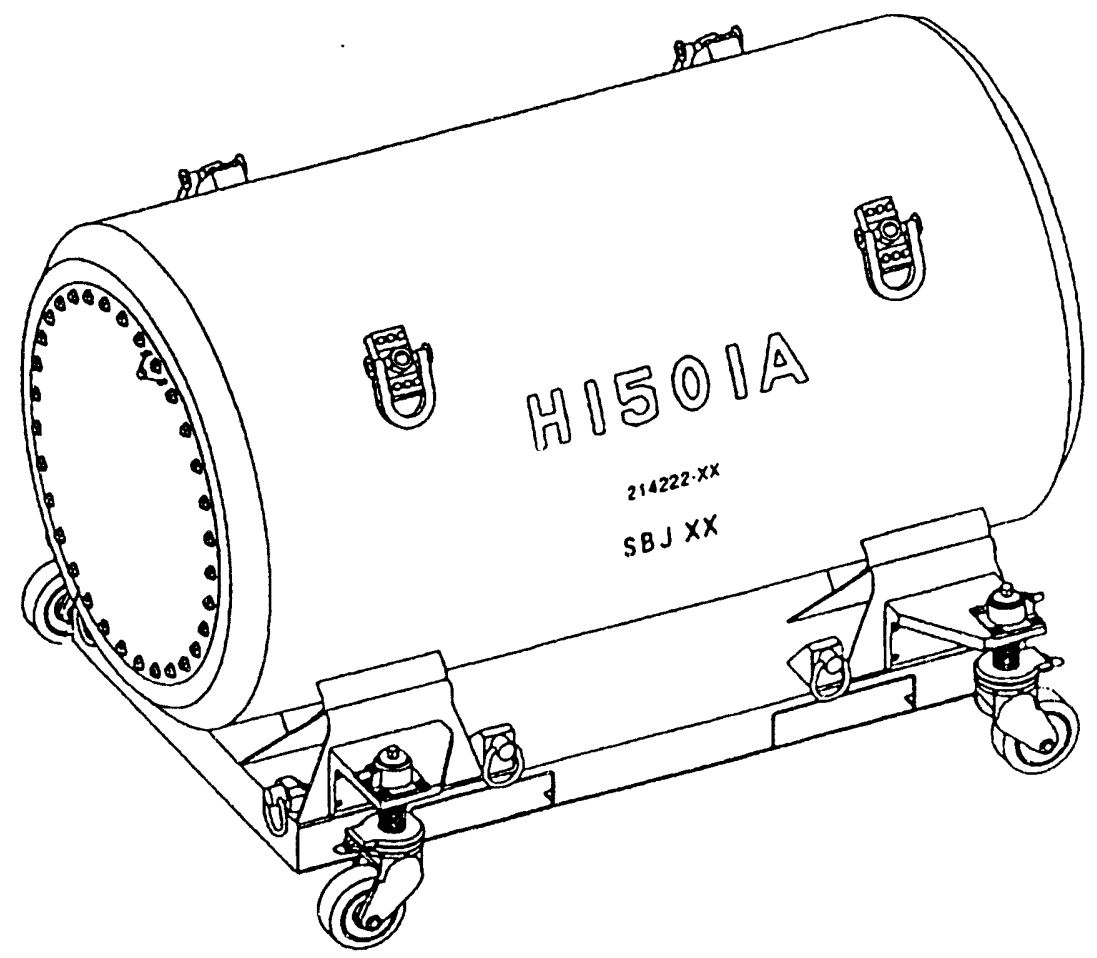

H1501A Transportation Accident Resistant Container 
pasediuo J sıau!e

SมอISES ON.

\begin{tabular}{|c|c|c|c|}
\hline (0) & 06 & $\nabla 2$ & 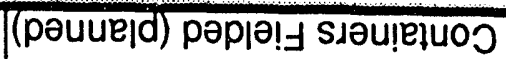 \\
\hline 198 & $\begin{array}{l}6 \angle M^{\prime} 0 \angle M \\
\angle S g^{\prime} 8 \pm M\end{array}$ & $\begin{array}{c}6 \angle M \\
\angle S g^{\prime} 8 D M\end{array}$ & suodezM \\
\hline . sql 00t2 & sql $00 \varepsilon 2$ & sql $G \angle 6 L$ & 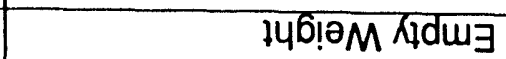 \\
\hline „S†//.ES/„Z8 & "St/,ES/.OL & .0t/..ES/..0L & 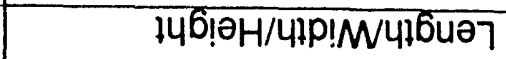 \\
\hline$: \nabla \varepsilon z^{\circ}: 0 \varepsilon \varepsilon L^{\circ}: 0 \varepsilon$ & $. S L E 8 . S t$ & $.0 \angle 28.06$ & slu!Od uMOO \\
\hline 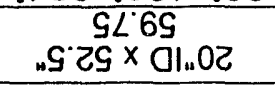 & $\begin{array}{c}S L \angle b \\
S \cdot 0 t \times a l .02 \\
\end{array}$ & $\begin{array}{c}S L \angle D \\
{ }^{S} O t \times 0 l_{4} 91\end{array}$ & 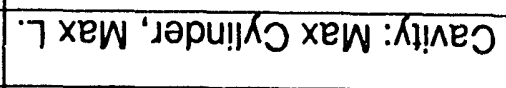 \\
\hline$" G^{\circ} L$ & $" S \cdot L$ &. $\mathcal{S}^{\prime} 9$ & 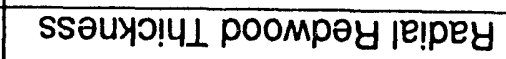 \\
\hline „0Z/.8E & .0Z/.8E & "9/.टE & 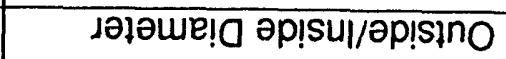 \\
\hline 8LOSLH & VLOSLH & LOSLH & \\
\hline
\end{tabular}

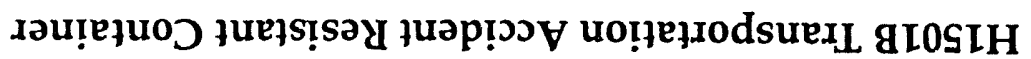

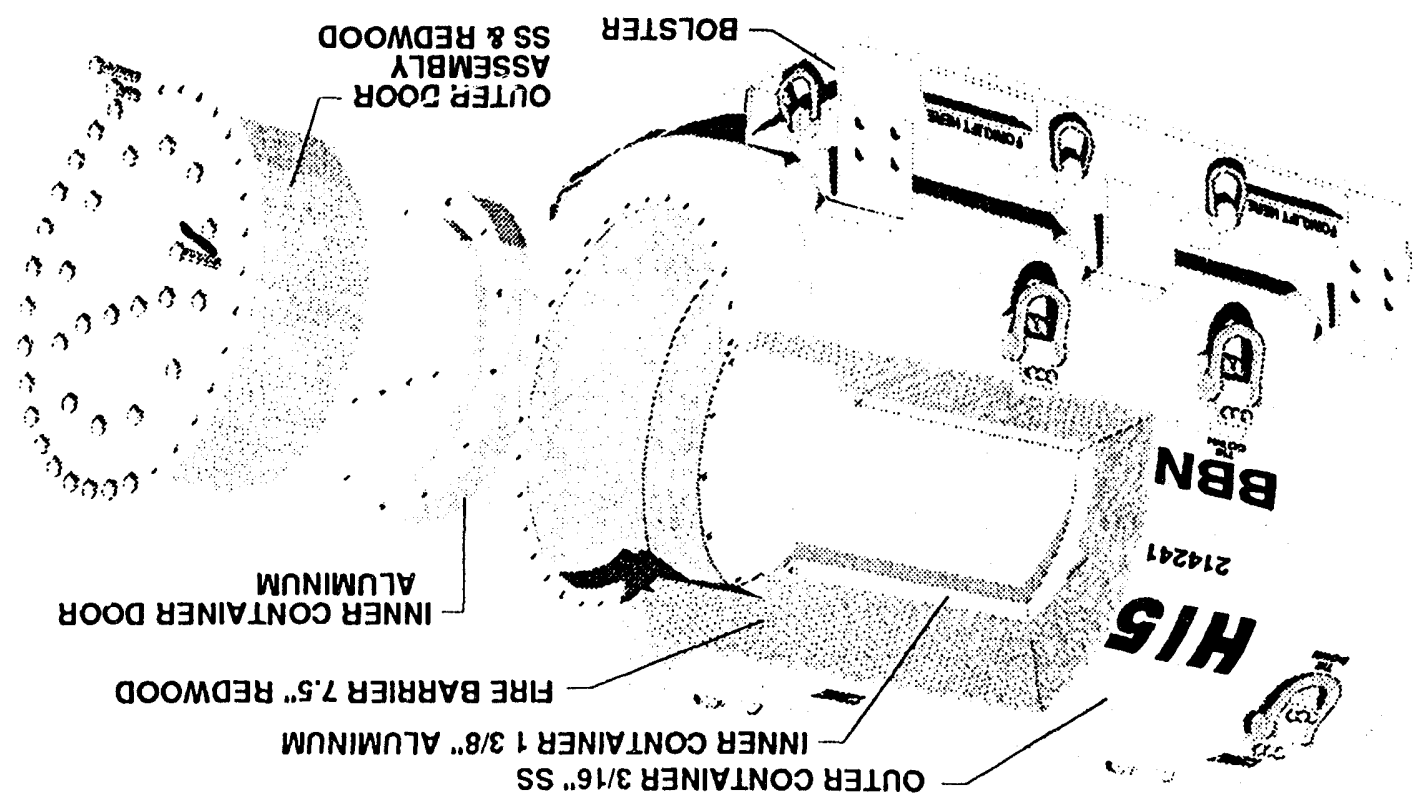




\section{Summary of H1501 and H1501A Tests}

Mid '70s Tests

$873 / 8$ scale impact tests, 10 full scale impact tests, and 2 full scale fire tests.

\section{Recent Tests}

\begin{tabular}{|c|c|c|c|c|}
\hline Test Unit & Test Date & Weapon & Test Conditions & Notes \\
\hline \multirow{3}{*}{ H1501 Unit A } & 26 September 1990 & \multirow{3}{*}{ W79 } & 147 FPS onto bolster & \\
\hline & 28 September 1990 & & 104 FPS onto door & \\
\hline & 6 Februrary 1991 & & 2.5 hour fuel fire & $\begin{array}{l}0.5 \text { hour extra because wind } \\
\text { cooled fire. Smolder queriched } \\
\text { after } 9 \text { days }\end{array}$ \\
\hline \multirow[t]{2}{*}{ H1501 Unit B } & 21 March 1991 & \multirow[t]{2}{*}{ W79 } & 163 FPS upside down & Worst orientation for weapon. \\
\hline & 10 April 1991 & & 2 hour fuel fire & Smolder self extinguished. \\
\hline H1501A Drop 1 & October 1991 & W48 & $\begin{array}{l}100 \text { FPS } \\
\text { approximate; upside } \\
\text { down on corner }\end{array}$ & $\begin{array}{l}\text { Desired } 225 \text { FPS but pull down } \\
\text { cables broke. }\end{array}$ \\
\hline H1501A Drop 1A & 22 January 1992 & W48 & $\begin{array}{l}100 \text { FPS } \\
\text { approximate; upside } \\
\text { down on corner }\end{array}$ & $\begin{array}{l}\text { Desired } 2.25 \text { FPS but pull down } \\
\text { cables broke. }\end{array}$ \\
\hline H1501A Drop 1B & 18 March 1992 & W48 & $\begin{array}{l}185 \text { FPS; upside } \\
\text { down on corner }\end{array}$ & $\begin{array}{l}\text { Desired } 225 \text { FPS but pull down } \\
\text { cables cut too soon. Worst } \\
\text { orientation for container. }\end{array}$ \\
\hline H1501A Burn 1B & 3 April 1992 & W48 & 2 hour fuel fire & $\begin{array}{l}\text { Drop 1B unit was burned. Tried } \\
\text { fire fighting techniques. }\end{array}$ \\
\hline H1501A Drop 2 & 1 April 1992 & W70 & 232 FPS upside down & Max g's into warhead \\
\hline H1501A Burn 2 & 22 April 1992 & & 2 hour fuel fire & Drop 2 unit was burned \\
\hline H1501A Drop 3 & 30 April 1992 & W70 & 227 FPS onto door & Reused container from Drop 1 \\
\hline
\end{tabular}




\section{SUMMARY OF TARC BURN TESTS}

\begin{tabular}{|c|c|c|c|c|c|}
\hline TEST & PAYLOAD & DATE & TEST CONDITIONS & TEST RESULTS & COMMENTS \\
\hline H1501 Burn A & Mass mock W79 & $2 / 6 / 91$ & $\begin{array}{l}2.5 \text { hour fuel fire; test } \\
\text { unit was not always fully } \\
\text { engulfed in fire }\end{array}$ & $\begin{array}{c}\text { Weapon } 192^{\circ} \mathrm{F} \text { at } 44 \\
\text { hours, } 300^{\circ} \mathrm{F} \text { sometime } \\
\text { later; Smolder quenched at } \\
9 \text { days }\end{array}$ & $\begin{array}{l}\text { Burned Drop A; Windy - } \\
\text { "cool" burn; Jetting at large } \\
\text { instrumentation holes; Long } \\
\text { smolder attributed to the holes }\end{array}$ \\
\hline H1501 Burn B & Stiffness mock W79 & $4 / 10 / 91$ & 2 hour fuel fire & $\begin{array}{l}\text { Weapon max } 212^{\circ} \mathrm{F} \text { at } 18 \\
\text { hours; Smolder self- } \\
\text { extinguished in } 5 \text { days }\end{array}$ & Burned Drop B \\
\hline H1501A Burn 1B & Structural mock W48 & $4 / 3 / 92$ & 2 hour fuel fire & $\begin{array}{l}\text { Weapon max } 170^{\circ} \mathrm{F} \text { at } 17 \\
\text { hours; Smolder was } \\
\text { extinguished at } 49 \text { hours }\end{array}$ & $\begin{array}{l}\text { Burned Drop 1B; tried fire } \\
\text { fighting techniques }\end{array}$ \\
\hline H1501A Burn 2 & Structural mock W70 & $4 / 22 / 92$ & 2 hour fuel fire & $\begin{array}{c}\text { Weapon } 200^{\circ} \mathrm{F} \text { at } 9 \text { hours; } \\
\text { smolder extinguished at } \\
\text { that time }\end{array}$ & $\begin{array}{l}\text { Burned Drop 2; Very windy } \\
\text { after the test; Smolder } \\
\text { extinguished to preserve } \\
\text { warhead for disassembly }\end{array}$ \\
\hline H1501B Burn 7 & Mass mock B61 & $10 / 21 / 92$ & 2 hour fuel fire & $\begin{array}{c}\text { Weapon max } 148^{\circ} \mathrm{F} \text { at } 48 \\
\text { hours; Smolder was } \\
\text { extinguished at } 49 \text { hours }\end{array}$ & $\begin{array}{l}\text { Burned Drop 7; Demonstrated } \\
\text { fire fighting approach for } \\
\text { smolder }\end{array}$ \\
\hline H1501B Burn 20 & Mass mock B57 & $7 / 15 / 93$ & 2 hour fuel fire & $\begin{array}{l}\text { Weapon } 230^{\circ} \mathrm{F} \text { at } 30 \\
\text { hours, } 360^{\circ} \mathrm{F} \text { peak at } 60 \\
\text { hours; Smolder continued } \\
\text { for more than } 12 \text { days }\end{array}$ & $\begin{array}{l}\text { Burned Drop 20; Highest } \\
\text { weapon temperature because } \\
\text { largest opening in skin and } \\
\text { some inner cylinder damage }\end{array}$ \\
\hline
\end{tabular}


SUMMARY OF TARC IMPACT TESTS

\begin{tabular}{|c|c|c|c|c|c|}
\hline TEST & PAYLOAD & DATE & TEST CONDITIONS & TEST RESULTS & COMMENTS \\
\hline \multirow[t]{2}{*}{ H1501 Drop A } & \multirow[t]{2}{*}{ Mass mock W79 } & $9 / 26 / 90$ & 147 fps onto bolster & no openings & --- \\
\hline & & $9 / 28 / 90$ & 104 fps onto door end & no openings & $\begin{array}{l}\text { Thermocouples cut, } \\
\text { Became Burn A }\end{array}$ \\
\hline H1501 Drop B & Stiffness mock W79 & $3 / 21 / 91$ & 163 fps upside down & $\begin{array}{l}\text { 2.7" crush on side; } 2 \text { holes } \\
\text { (casters) }\end{array}$ & $\begin{array}{c}\text { Worst orientation for } \\
\text { weapon; Became Burn B }\end{array}$ \\
\hline H1501A Drop I & Structural mock W48 & $10 / 23 / 91$ & $\begin{array}{l}100 \text { fps upside down, door } \\
\text { end up ( } 10^{\circ} \text { slapdown) }\end{array}$ & $\begin{array}{c}1 " \text { crush on side; no } \\
\text { openings }\end{array}$ & $\begin{array}{c}\text { Pull-down cable broke } \\
\text { (desired } 225 \text { fps slapdown) }\end{array}$ \\
\hline H1501A Drop 1A & Structural mock W48 & $1 / 22 / 92$ & 86 fps upside down & $\begin{array}{l}\text { two holes opened landing } \\
\text { on pull down cable pulleys }\end{array}$ & $\begin{array}{c}\text { Pull-down cable broke } \\
\text { (desired } 225 \text { fps slapdown) }\end{array}$ \\
\hline H1501A Drop 1B & Structural mock W48 & $3 / 18 / 92$ & $\begin{array}{l}185 \text { fps upside down, door } \\
\left.\text { end down ( } 19^{\circ} \text { slapdown }\right)\end{array}$ & $\begin{array}{l}7.4^{\prime \prime} \text { crush at corner; } 2 " \\
\text { crush on side; one hole } \\
\text { (caster) }\end{array}$ & $\begin{array}{c}\text { Pull-down cable broke } \\
\text { (desired } 225 \text { fps slapdown); } \\
\text { Worst orientation for } \\
\text { weapon; Became Burn 1B }\end{array}$ \\
\hline H1501A Drop 2 & Structural mock W70 & $4 / 1 / 92$ & 232 fps upside down & $\begin{array}{l}3.8 " \text { crush on side; three } \\
\text { holes (casters) }\end{array}$ & Became Burn 2 \\
\hline H1501A Drop 3 & Mock W70 & $4 / 30 / 92$ & 227 fps onto door end & $\begin{array}{l}4.6 " \text { crush at door end; no } \\
\text { openings }\end{array}$ & $\begin{array}{c}\text { H1501A was reused from } \\
\text { Drop 1 }\end{array}$ \\
\hline H1501B Drop 7 & Mass mock B61 & $9 / 16 / 92$ & $\begin{array}{l}229 \text { fps upside down, door } \\
\text { end down }\left(23^{\circ} \text { slapdown }\right)\end{array}$ & $\begin{array}{l}9 " \text { crush at corner; } 2.6 " \\
\text { crush on side; two small } \\
\text { tears }\end{array}$ & Became Burn 7 \\
\hline H1501B Drop 5 & Mass mock B61 & $3 / 4 / 93$ & 225 fps CG over corner & $\begin{array}{l}11 " \text { crush at corner; two } \\
\text { small tears }\end{array}$ & -- \\
\hline H1501A Drop 8 & Mass mock W69 & $3 / 10 / 93$ & 237 fps upside down & $\begin{array}{c}3.5 " \text { crush on side; no } \\
\text { openings }\end{array}$ & $\cdots$ \\
\hline $\begin{array}{l}\text { H1501A Drop } 20 \\
\text { "Impact Objects" }\end{array}$ & Mass mock B57 & $6 / 23 / 93$ & $\begin{array}{l}239 \text { fps upside down onto: } \\
\text { 1) caster and 2) simulated } \\
\text { C141 floor panel }\end{array}$ & $\begin{array}{l}3.8 " \text { crush on side; } 6 " \text { x } 8 " \\
\text { hole caused by caster yoke; } \\
\text { Inner cylinder damage }\end{array}$ & $\begin{array}{l}\text { Largest opening of all } \\
\text { impact tests to date. } \\
\text { Became Burn } 20 \\
\end{array}$ \\
\hline $\begin{array}{l}\text { H1501 A Drop } 21 \\
\text { "Glancing Impact" }\end{array}$ & Mass mock B57 & $7 / 22 / 93$ & $\begin{array}{l}323 \text { fps upside down onto } \\
\text { target inclinded at } 45^{\circ} ; 16^{\circ} \\
\text { slapdown on door end }\end{array}$ & $\begin{array}{l}5.2^{\prime \prime} \text { crush at door end; } 2 \\
\text { holes (casters) and } 2 \text { holes } \\
\text { (tiedown shackels) }\end{array}$ & $\begin{array}{l}\text { Highest velocity impact: } \\
\text { Total area of opeinings } \\
\text { similar to DROP-20 }\end{array}$ \\
\hline H1501A Drop 9 & Realistic W69 & 9/9/93 & $\begin{array}{c}235 \text { ???? fps upside down } \\
\text { onto tiedown chain on } \\
\text { C141 floor panel }\end{array}$ & $\begin{array}{l}3.1 " \text { crush on side; small } \\
\text { openings from tiedown } \\
\text { chain and panel stiffners }\end{array}$ & $-\cdots$ \\
\hline
\end{tabular}


UNCLASSIFIED

H1501; H1501A, and H1501B Compared

\begin{tabular}{|c|c|c|c|}
\hline & 11501 & $11501 \mathrm{~A}$ & 15015 \\
\hline Outside Diameter & $32^{\prime \prime}$ & 88" & $388^{\prime \prime}$ \\
\hline Inside Diameter & $1 \sigma^{\prime}$ & $20^{\prime \prime}$ & 201 \\
\hline Redwood Thickness & 6.51 & 7.5 & 7.5 \\
\hline Length / Width / l leight & $70^{\prime \prime} / 58^{\prime \prime} / 40^{\prime \prime}$ & $70 \% \cdot 58 \%: 45$ & $82:-53$ : 15 \\
\hline Empty Weight & $1975 \mathrm{los}$ & $2300 \mathrm{los}$ & 2406.105 \\
\hline Weapons & W48, B57, Wr9 & 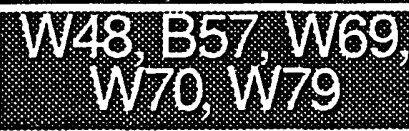 & $\mathbf{8 6 1}$ \\
\hline Containers Fielded & 24 & $(2,111$ & 55 \\
\hline
\end{tabular}

UNCLASSIFIED 


\section{Unlimited Release}

Initial Distribution:

U. S. Department of Energy

Albuquerque Operations Office

Attn: H. T. Season, Jr., Director WPD

A. E. Whiteman, Director WQD

M. C. Baca, WPD

K. L. Smithson, WPD

F. Jaramillo, WPD

P. O. Box 5400

Albuquerque, NM 87115

U. S. Department of Energy

Kansas City Area Office

Attn: C. C. Ross

P. O. Box 419159

Kansas City, MO 64141-6159

U. S. Department of Energy

Field Office, Oak Ridge

Attn: Central Library

For: S. A. Watkins, QL

P. O. Box 2001

Oak Ridge, TN 37831-8764

Allied-Signal Inc.

Attn: R. G. Gemeinhardt, D/005

P. F. Ross, D/231

D. C. Steinke, D/231 (1D40)

W. G. Cooper, D/800

D. S. Douglas, D/811

P. O. Box 419159

Kansas City, MO 64141-6159

Allied-Signal Inc.

Attn: K. F. Arnold, D/811

P. O. Box 419159

Kansas City, MO 64141-6159

University of California

Lawrence Livermore National Laboratory

Attn: G. L. Ditman, L-125

L. P. Altbaum, L-125

P. O. Box 808

Livermore, CA 94550 
Los Alamos National Laboratory

Attn: L. B. O'Brien, ESA-11 MS C931

R. W. Taylor, MS P945

P. O. Box 1663

Los Alamos, NM 87545

MS0517 D. W. Doak, Actg., 2700

Attn: M. S. Garrett, 2761

MS0463 R. L. Hagengruber, 5000

Attn: H. J. Saxton, 5400

C. S. Yarnall, 5500

D. B. Hayes, 5600

MS0429 W. C. Nickell

Attn: J. O. Harrison, 5115

D. D. Tipton, 5151

R. L. Alvis, 5165

MS9005 J. B. Wright, 5300

Attn: D. J. Bohrer, 5303

D. R. Henson, 5354

C. T. Oien, 5361

C.A. Pura, 5321

D. J. Beyer, 5363

R. G. Miller, 5366

MS9035

R. D. Monson, 5364 (2)

MS9035

P. Lari, 5365

MS9035

G. C. Story, 5365

MS9001

J. C. Crawford, 8000

Attn: E. E. Ives, 5200

M. E. John, 8100

R. J. Detry, 8200

L. A. Hiles, 8400

P. N. Smith, 8500

L. A. West, 8600

R. C. Wayne, 8700

MS9022 Mail Distribution, 8533-1 for OSTI (10)

MS9022 Mail Distribution/Technical Library Processes

MS0899 Technical Library Processes Department, 7141 (4)

MS9018 Central Technical Files, 8523-2 (3) 

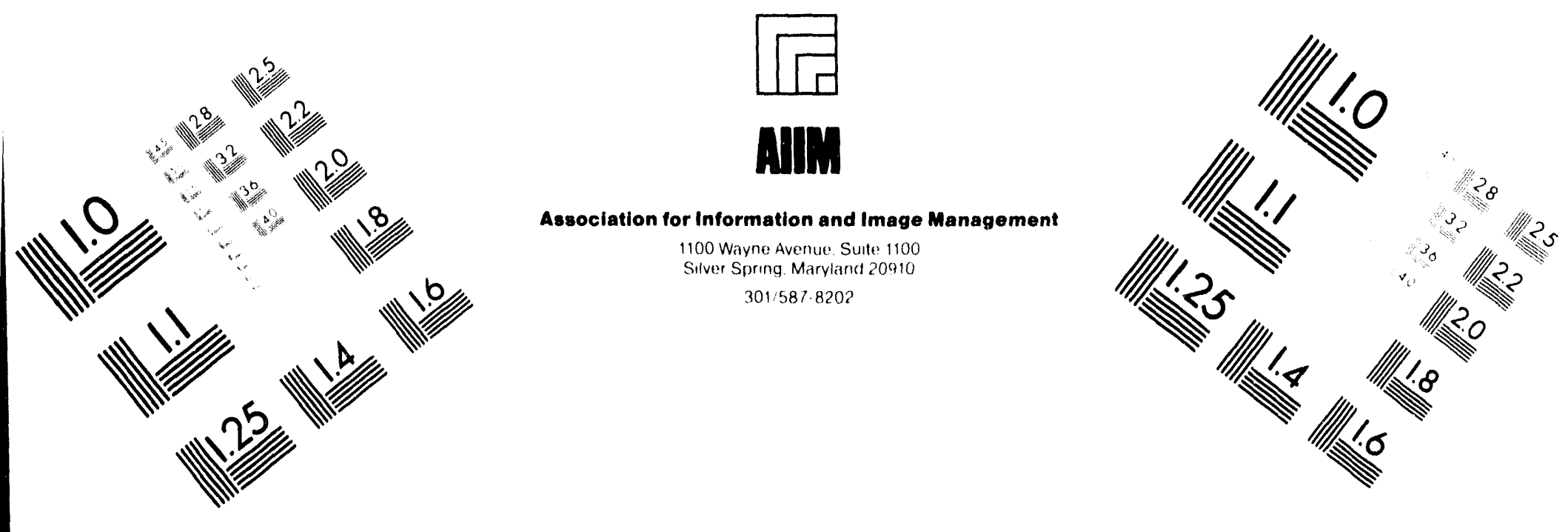

\section{Centimeter}

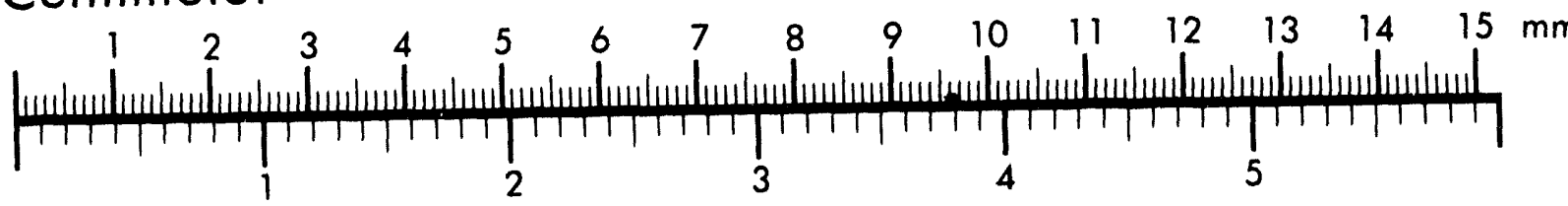
Inches
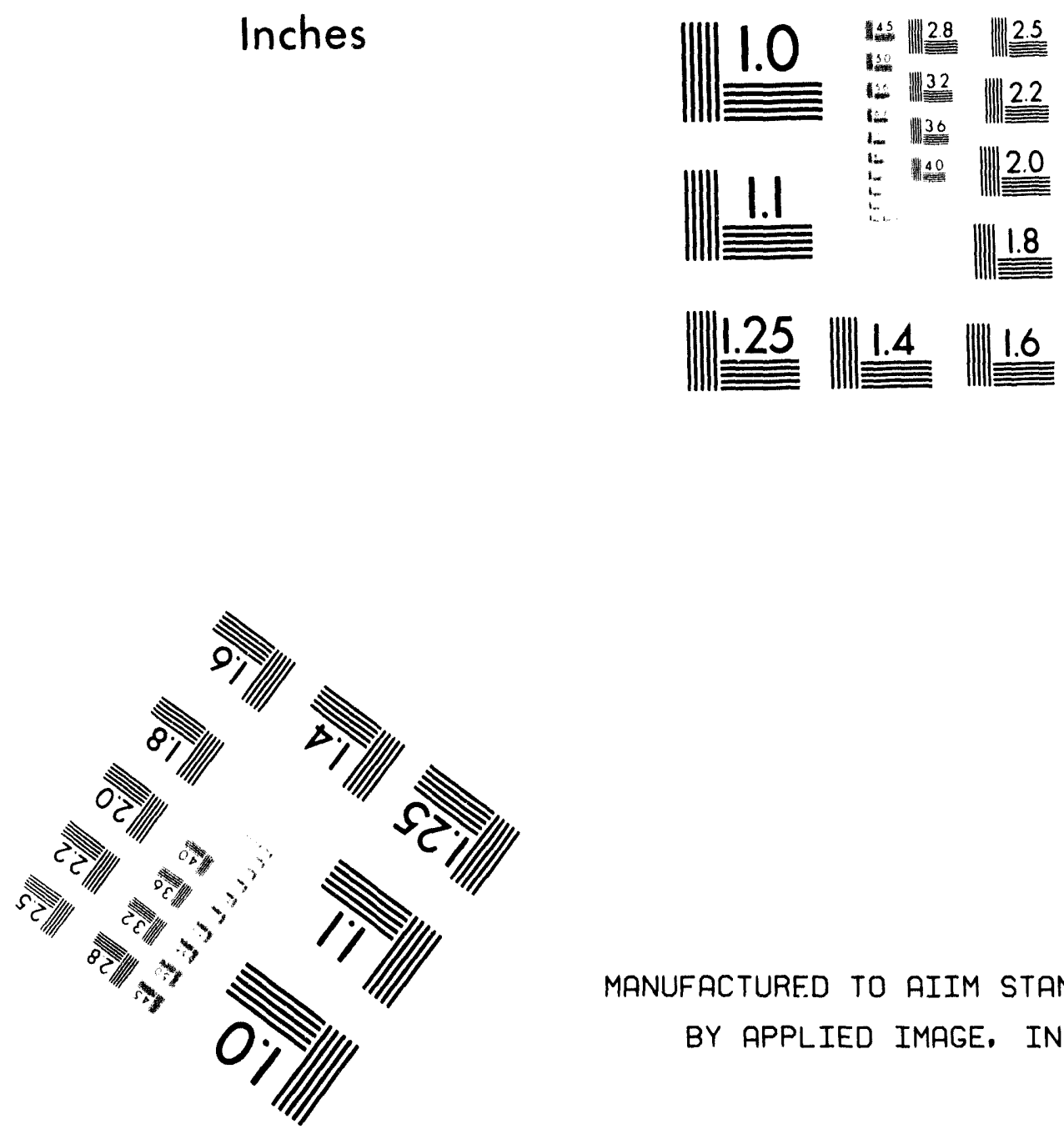

MANUFACTURED TO AIIM STANDARDS

BY APPLIED IMAGE, INC.

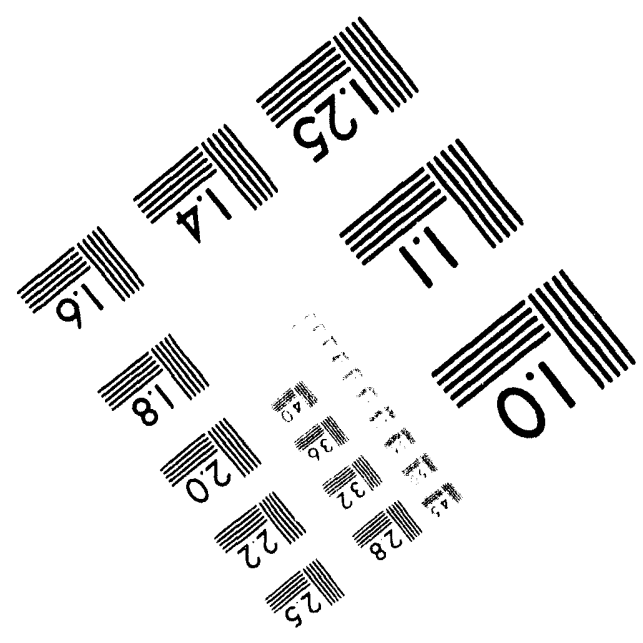


- 

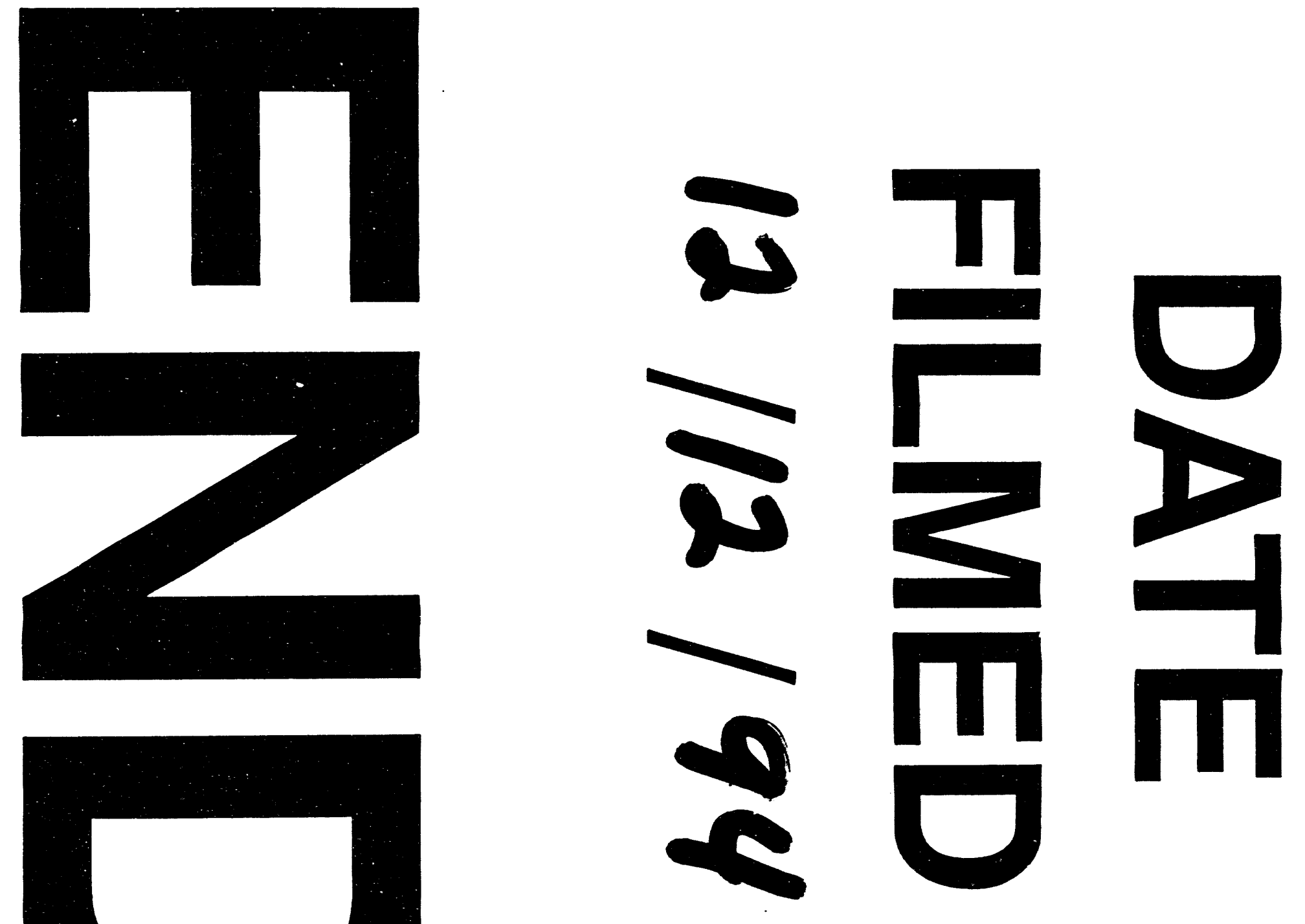